University of Louisville

ThinkIR: The University of Louisville's Institutional Repository

Electronic Theses and Dissertations

$12-2010$

\title{
Using simulation as a tool to improve a multi-product paint process.
}

Paul-Victor Heitz 1983-

University of Louisville

Follow this and additional works at: https://ir.library.louisville.edu/etd

\section{Recommended Citation}

Heitz, Paul-Victor 1983-, "Using simulation as a tool to improve a multi-product paint process." (2010). Electronic Theses and Dissertations. Paper 601.

https://doi.org/10.18297/etd/601

This Master's Thesis is brought to you for free and open access by ThinkIR: The University of Louisville's Institutional Repository. It has been accepted for inclusion in Electronic Theses and Dissertations by an authorized administrator of ThinkIR: The University of Louisville's Institutional Repository. This title appears here courtesy of the author, who has retained all other copyrights. For more information, please contact thinkir@louisville.edu. 


\title{
USING SIMULATION AS A TOOL TO IMPROVE A MULTI-PRODUCT PAINT PROCESS
}

\author{
By \\ Paul-Victor Heitz \\ B.S., University of Dayton, 2006
}

\author{
A Thesis \\ Submitted to the Faculty of the \\ Graduate School of the University of Louisville \\ in Partial Fulfillment of the Requirements \\ for the Degree of \\ Master of Science \\ Department of Industrial Engineering \\ Speed Scientific School \\ University of Louisville \\ Louisville, Kentucky
}

December 2010 



\title{
USING SIMULATION AS A TOOL TO IMPROVE A MULTI-PRODUCT PAINT PROCESS
}

\author{
By \\ Paul-Victor Heitz \\ A Thesis Approved on \\ May 21, 2010 \\ by the following Reading Committee: \\ Dr. Gerald W. Evans, Thesis Director
}

Dr. William E. Biles

Dr. Dar-Jen Chang 


\begin{abstract}
USING SIMULATION AS A TOOL TO IMPROVE A MULTI-PRODUCT PAINT PROCESS

Paul-Victor Heitz
\end{abstract}

May 21, 2010

DENIOS manufactures steel structures for the storage, handling and containment of chemicals. The company has recently relocated into a larger manufacturing facility. This move will allow the manufacturing capacity of the company to grow for the three types of products: pallets, lockers and containers made by the company. However, the current painting capabilities of the company's paint department cannot grow as easily as the rest of the areas of the manufacturing process. This paper discusses ways the company can decrease the cycle times of products being sent through the paint department. By applying color blocking to arrival rates of some of the products, applying concepts of factory physics and Little's Law to reduce work in process and optimizing the batching process, the company can reduce the cycle time of the products. 


\section{TABLE OF CONTENTS}

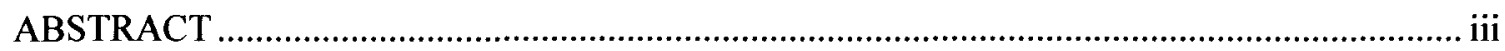

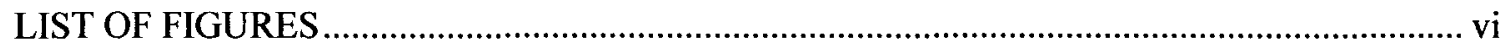

CHAPTER 1. INTRODUCTION

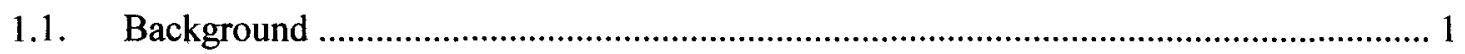

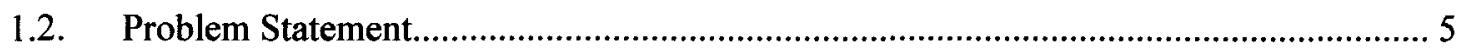

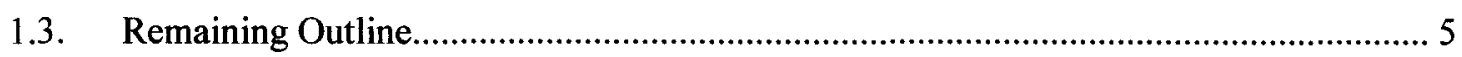

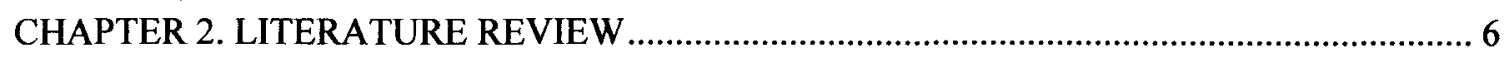

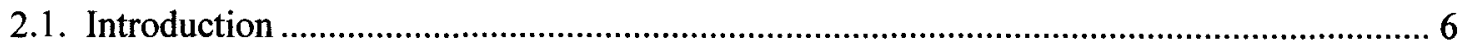

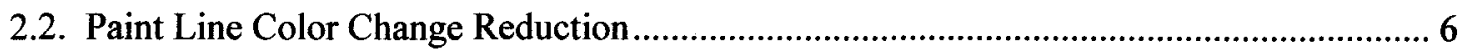

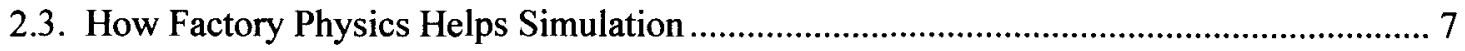

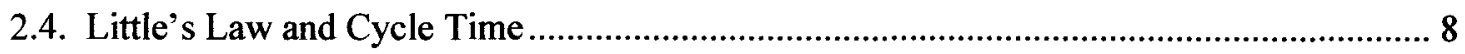

2.5. Optimization Approaches for Batch Processes ............................................................. 9

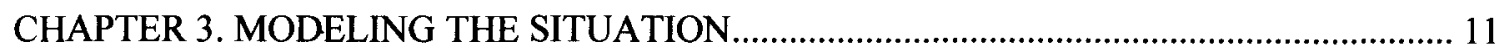

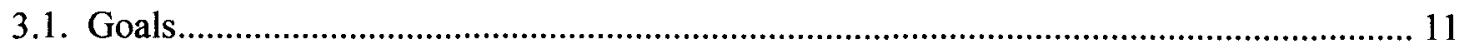

3.2. Modeling of the Problem Situation ........................................................................... 11

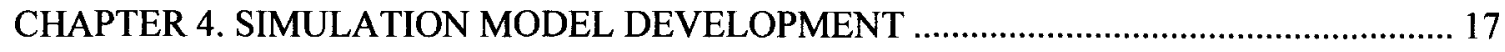

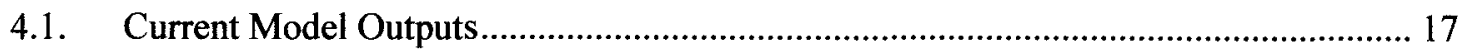

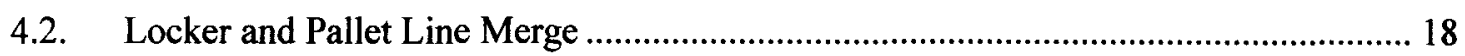


4.3. Adding Additional Paint Resources

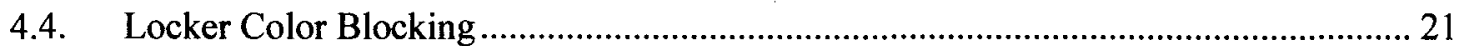

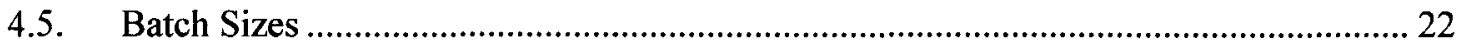

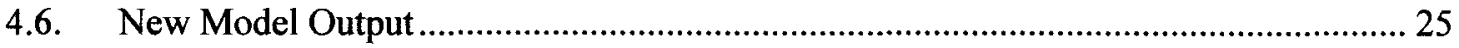

CHAPTER 5. CONCLUSIONS AND FURTHER RESEARCH ............................................ 27

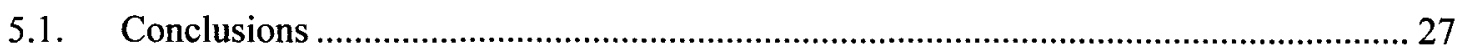

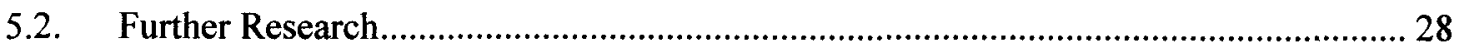

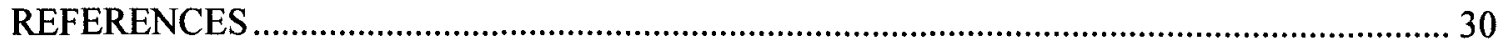

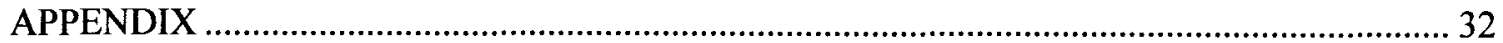

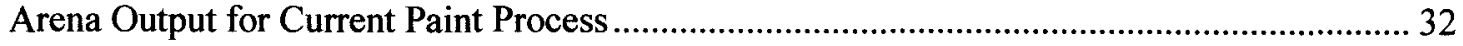

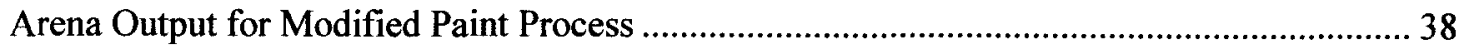

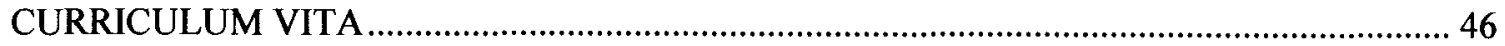




\section{LIST OF FIGURES}

Figure 1 Example of Container Product …............................................................................... 2

Figure 2 Example of Locker Product …............................................................................... 3

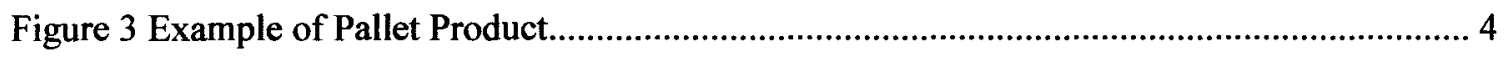

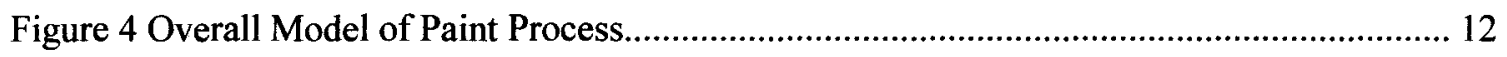

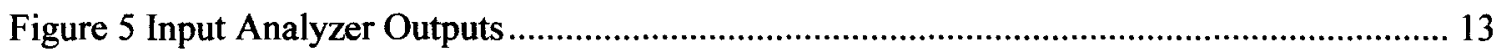

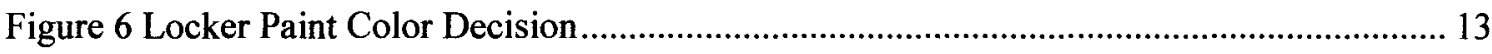

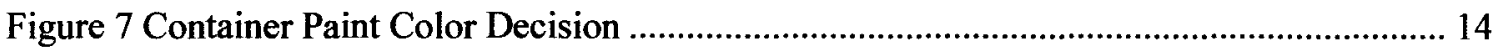

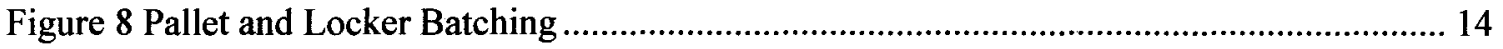

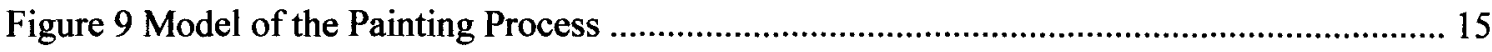

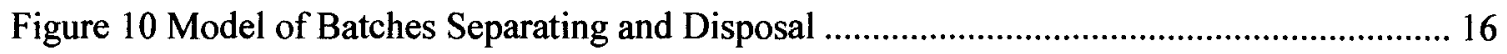

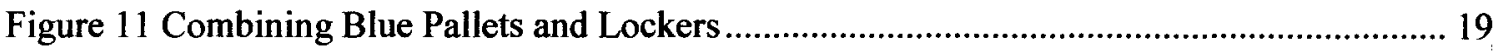

Figure 12 Decide Module to Decide Product Type ............................................................. 19

Figure 13 Modified Paint Process with Paint Additional Resources........................................... 21

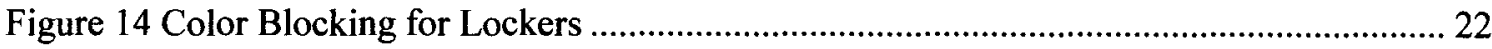

Figure 15 Overview of the Modified DENIOS Paint Process ....................................................... 25 


\section{CHAPTER 1. INTRODUCTION}

\subsection{Background}

DENIOS is a company that manufactures steel structures for the storage, handling and containment of chemicals. The company recently moved into an 80,000 square foot manufacturing facility which is a larger facility was at its than previous location. This move will allow the manufacturing capacity of the company to grow.

A vast majority of the products manufactured are welded hot rolled steel components and must be routed through the company's paint department to be painted in order to provide a nice finished look and prevent corrosion. The company currently utilizes a 24 by 60 foot paint booth that is sized large enough to accommodate the largest sized units the company offers.

There are three main types of products that are manufactured and arrive to the paint processing area of the shop. The first are containers which are large storage systems the company produces. Containers are buildings or cabinets that are storage enclosures to store, mix, dispense, or process chemicals in a safe, secure environment providing secondary spill containment. See Figure 1 for an example of a container product. 


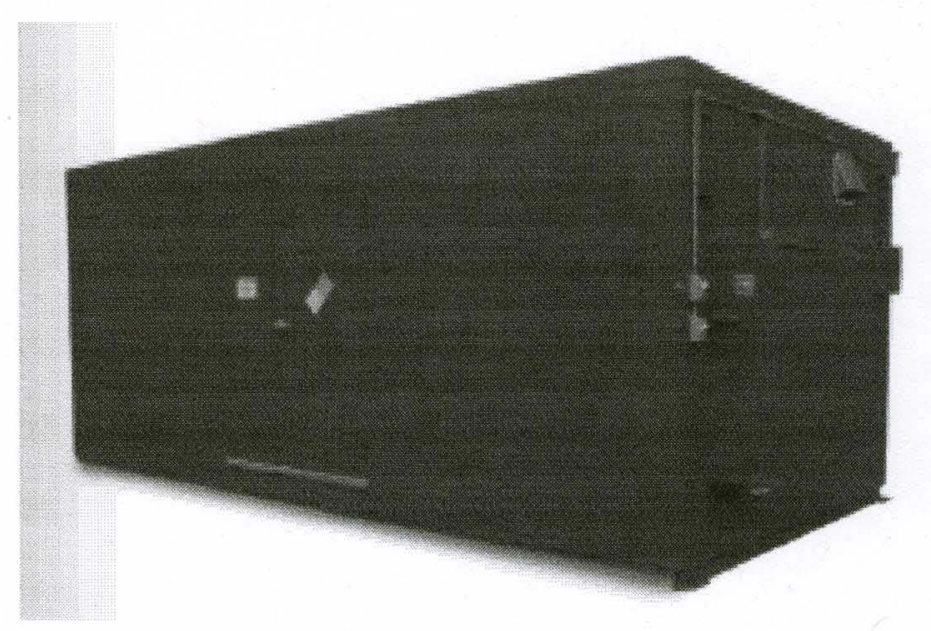

Figure 1 Example of Container Product

The second product type is lockers which are midsized storage units. DENIOS's lockers are designed for enclosed storage of small numbers of drums or IBC totes indoors or outside of customer's facilities, separating personnel from hazardous materials while providing safe, secure storage. Like containers they provide secondary spill containment. See Figure 2 for an example of a locker product. 


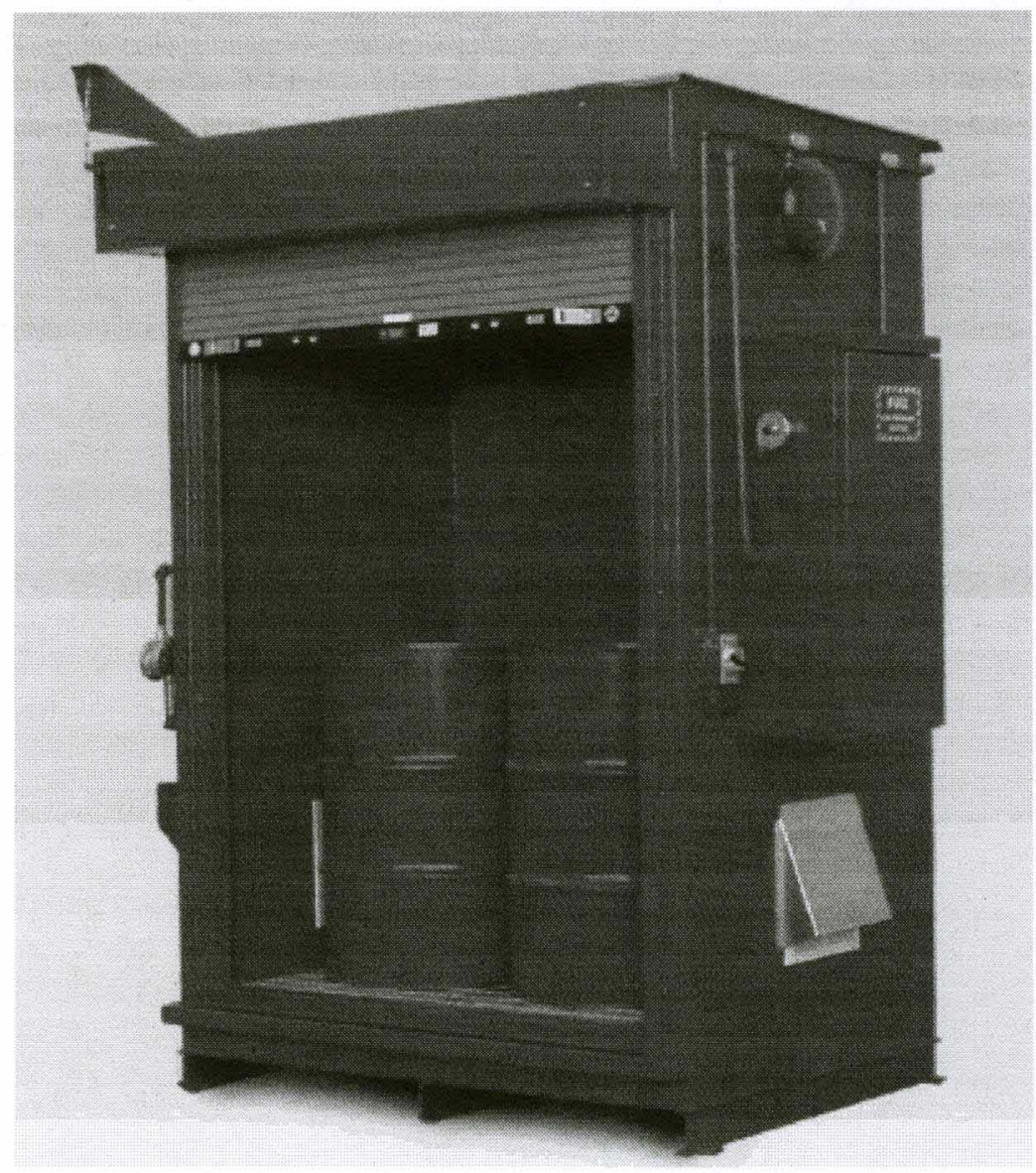

Figure 2 Example of Locker Product

The last of the product types are described as pallets. They are formed steel sump designed to provide secondary containment for spill and leaks. See Figure 3 for an example of a pallet product. 


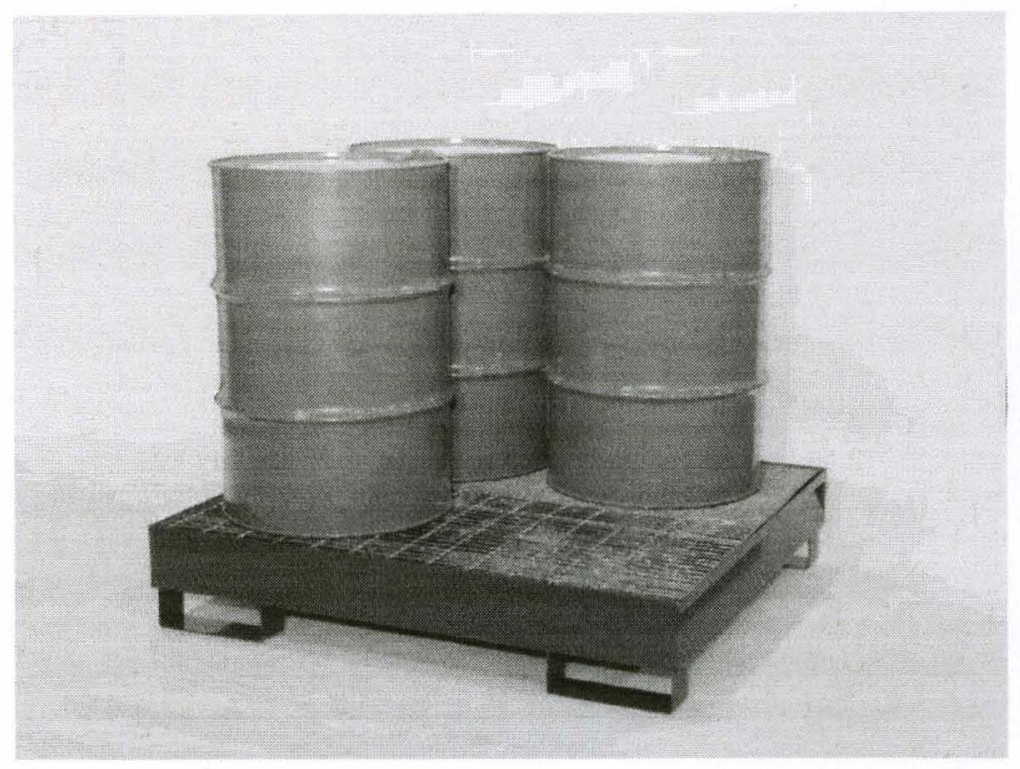

Figure 3 Example of Pallet Product

The mix of products that arrive to the paint area consists of mostly the pallet products. A smaller percentage is the lockers and the smallest number of arrivals is containers. Products arrive to the paint area from the three production areas of the shop. Since container products are large, they occupy most of the floor space of the paint booth by themselves. Because of size and promised ship dates, containers take a high priority to get painted. This product has a polysiloxane coating and comes in one of three colors: blue, white or tan. Pallets and lockers are set aside until there are enough of the same types to be grouped together to be placed into the paint booth at the same time. Pallets are only offered in the blue color and painted with a polyurethane coating. Lockers are available in either blue or white and have a polysiloxane coating.

When a group of products are selected to be painted they first go through a pre-paint process before being placed into the booth to be coated. All surfaces are prepared to be coated by wiping them down with a cleaning product to remove dirt, weld dust and leak test residue out of the sumps. Also, weld spatter is scrapped and removed. Then, when necessary seams are caulked, unpainted surfaces are taped off. 
After the pre-paint process the product is transported into the paint booth. Paint lines are prepared and the amount of paint needed to paint the batch is mixed. Once the paint is ready the items are coated with paint. When completed items are transported out of the paint booth to the finishing department to allow drying of the paint and final assembly.

\subsection{Problem Statement}

According to the Operations Manager, the paint department is the bottleneck of the manufacturing process. (Woosley 2009) This means that the paint department's capacity limits the total output of the company's entire production process.

Due to the recent move into the larger facility the shop floor space for the assembly of products is allowed to grow relatively easily. However, the paint booth size and capacity cannot grow without large capital investments to purchase larger painting capabilities or outsourcing some of the painting somewhere else. Without the ability to grow in capacity, the bottleneck in the paint area will be amplified. By understanding the current process and improving upon it the company can make the most out of the current space on the shop floor and increase the throughput of the production line.

\subsection{Remaining Outline}

In the remainder of this text a number of goals will be accomplished. First, a literature review of articles will give insight into points of current knowledge dealing with topics that might aid in ways to improve the paint process. Next, the hypothesis and the current problem model situation is laid out. Then, the model will be run to generate current numbers for the process. After, improvements are made to the model. Once the new model is ran then they can be compared to the current model numbers to analyze the improvements to the paint process. 


\section{CHAPTER 2. LITERATURE REVIEW}

\subsection{Introduction}

There are many pertinent topics that will be covered in the review of literature, which are: color blocking, factory physics principles and optimization techniques. Each of these topics will help create a better understanding of DENIOS's paint process and help steer in ways to improve it.

\subsection{Paint Line Color Change Reduction}

In an automobile manufacturing system the painting is an important part of the entire process. However, not every vehicle is painted the same color. In a typical automotive company the sequence of cars in a production line are based mostly on line balancing and material management. In the article "Paint Line Color Change Reduction in Automobile Assembly Through Simulation" (Han, et al. 2003) addresses that since those factors are so important the painting station is looked at less.

Since work load balancing is considered so important, the creation of color blocks (the creation consecutively-sequenced cars of the same color) is less important. This leads to more color changes. Each time the color is changed the plant must cleanse the painting apparatus in order to move to the next car. As a result, there is a cost associated to each color change due to the paint that is wasted in the process and the solvent that is used during the change. 
To optimize the problem the authors minimized the total number of color changed based on the ordering of the automobiles and the colors they are to be painted. In other words, they wanted larger color blocks in the process. Discrete event simulation is the tool used in the paper to analyze the issue to select an algorithm.

\subsection{How Factory Physics Helps Simulation}

Factory physics provides laws that that describe the behaviors of systems. The article "How Factory Physics Helps Simulation" (Standridge 2004) shows ways that the applications of specific factory physics laws to the activities of a simulation project.

The first law discussed is the conservation of material law. It states that in a stable system, over a long period of time that the rate that exits the system will equal the rate entering the system plus any yield loss inside the system. It is expressed in Equation 3:

$$
\text { Rate }_{\text {out }}=\text { Rate }_{\text {in }}+\text { Rate }_{\text {loss }}
$$

This law is useful to verify whether or not a system is valid. Also, it can verify that the conversions between batch sizes between each component were done correctly.

The next topic looked at is the station cycle time definition. This states that the average cycle time at a station can be obtained by adding the average time spent at each component of the operation such as transport, time in queue, setup time, processing time, et cetera.

Little's Law is a topic covered. It is stated as the throughput equals the work in process divided by the cycle time and shown in Equation (4):

$$
T H=W I P / C T
$$

Cycle time and WIP are common simulation performance measurements. Little's Law can be used as verification in a simulation model.

Other tools looked at in the article are variability buffering which is the law that sates variability will be buffered by some combination of inventory, capacity and lead time. Practical 
worst case definition is the maximum randomness that an entity is likely to be at any workstation. This definition makes assumptions about distribution of arrival times. Conducting experiments to a model based on variability can be used to ensure conclusions are not overly dependent on distribution assumptions made.

Utilization Law says that if the utilization of a station increases, the average WIP and cycle time increase in a nonlinear fashion. It is important to model a situation with regard to the mean standard deviation of the distribution in use. Otherwise, it may lead to the imprecise estimates of cycle time and WIP.

The last topic discussed is constant work in process or ConWIP laws. This is the maximum amount of WIP allowed at a workstation as a pre-specified parameter or that the WIP level is treated as very near to a constant.

All of these factory physics laws assist in performing simulation projects by validating and verifying models, defining performance, and finding alternatives for evolution.

\subsection{Little's Law and Cycle Time}

In the paper "Using Little's Law to Estimate Cycle Time and Cost" (Rust 2008) the author uses one of the factory physics topics, Little's Law, in order to display the prediction of operating conditions and associated cost effects of them. Also, Simple examples are used to back up her cases.

Little's Law, as stated previously in Equation 4, is defines the throughput of a system as the long term average of the work in process divided by the cycle time. Thus, there are two variables that can alter the through put and four different scenarios that can occur:

1. Throughput decreases and the WIP increases

2. Throughput increases and the WIP increases

3. Throughput increases and the WIP decreases 
4. Throughput decreases and the WIP decreases

The fist scenario in the article is an example of a sub optimal example due to possible poor operation policies. Scenario 2 is an instance where capacity limits are improved such as in adding capacity to a bottle neck because with the increase in capacity the queue levels improve. The third situation predicts that the cycle time will decrease because there was an excess in capacity that was available or improved operating polices were used. The last scenario can help increase cycle time in a factory where work in process and throughput have high variability. This can be done by having better policies in work balance in station queues to lower variability.

The author goes on to discuss the often asked question about what the cost is with a change in cycle time. The benefit to increasing the cycle time is that there is a value to customer responsiveness and manufacturing simplicity. However, it is difficult to put a dollar amount on this. Often there are draw backs in costs that are incurred when increasing throughput. Some of these may be associated with capital cost for new equipment, probability of lower cycle time product orders being filled before those with longer times, more material handling, and more storage requirements due to higher inventories. It is important to weigh costs before making changes to make sure it will be beneficial.

\subsection{Optimization Approaches for Batch Processes}

Scheduling is a key component in fabrication productivity when it comes to batch processes. Objectives like cycle time and throughput must be optimized to remain competitive in the marketplace. The article titled "Simulations-Based and Solver-Based Optimization Approaches for Batch Processes In Semiconductor Manufacturing"' (Klemmt, et al. 2008) discusses how these factors are addressed in a semi conductor fabrication process. In the problem 
described in the article looks to optimize the scheduling of a special oven machine group using different strategies.

The first method in uses mathematical mixed integer programming to optimize the problem. Parameters such as number of machines, lot size, and max number of batches are defined. Next, the constraints of the problem are developed in order to formulate the basis of the model. Based on the constraints that are formed different objective functions can be formed to optimized different aspects of the problem such as cycle time, queuing time, and minimization of the sums of batch start times.

The next section of the article discusses a way to solve practical more complex models using heuristic optimization methods using simulation. The simulation model is presented and the programs heuristic search algorithm evaluates the objective function that was entered. It then manipulates the control variables. It then runs the simulation again with the changed conditions and evaluates them as it runs in order to come up with heuristically comes up with a result.

The last point in the article points out how the models run in the examples were of a static model. A rolling forecast can be utilized in order to break up long time periods into sections. This way with varying product production needs, batch sizes can be optimized even more effectively. 


\section{CHAPTER 3. MODELING THE SITUATION}

\subsection{Goals}

The object is to take the cycle time information gathered from the current paint process using the Arena simulation program and to improve the process and maximize as much as possible the cycle time as much as possible. The goal is to find ways of doing this by concentrating on changing the way processes are executed and not looking at options that involve solutions that require large fiscal investments by the company. This way the company can learn how much more can be manufactured before measures have to be taken to increase the manufacturing capabilities of the paint process utilizing the existing paint booth capabilities.

\subsection{Modeling of the Problem Situation}

Computer simulation programs area a great tool to use in order model complex problems and help draw valid conclusions. In order to model the paint department process Arena simulation software is used. The program utilizes modules to represent logic in the system. Then they are connected to show the flow of the entities through the system. Once the system is built and ran statistical data can be drawn and analyzed. Figure 4 illustrates an overall model of the paint process. 

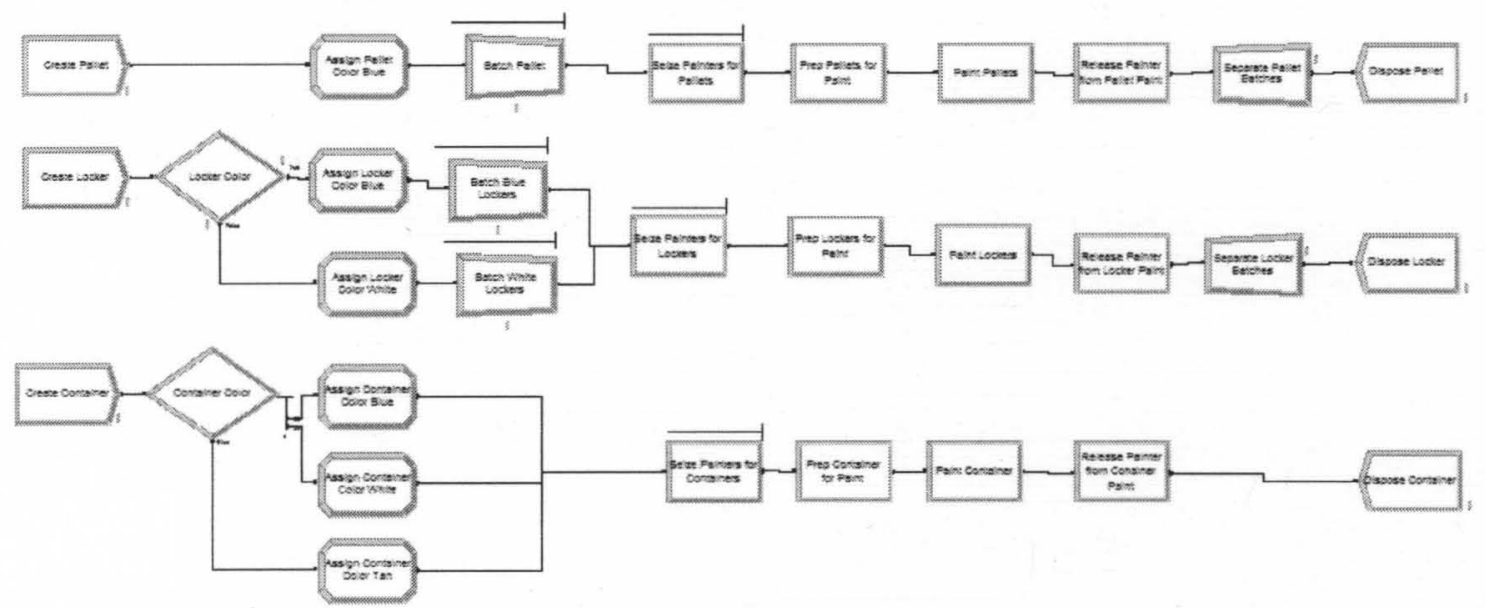

Figure 4 Overall Model of Paint Process

The three product lines arrive to the paint area. This is modeled using three separate Create Modules. This way there can be three different arrival rates based on the three different product types. Arrival rates were determined by looking at the 2009 schedule and placing the number of days in between arrivals into a text file for each of the three product types. These files were imported into Arena's Input Analyzer to establish arrival rates for the model by using the fit all features in order to obtain the distribution with the lowest square error value. The expressions from output in Figure 5 were placed into the Create Modules of the three products. 


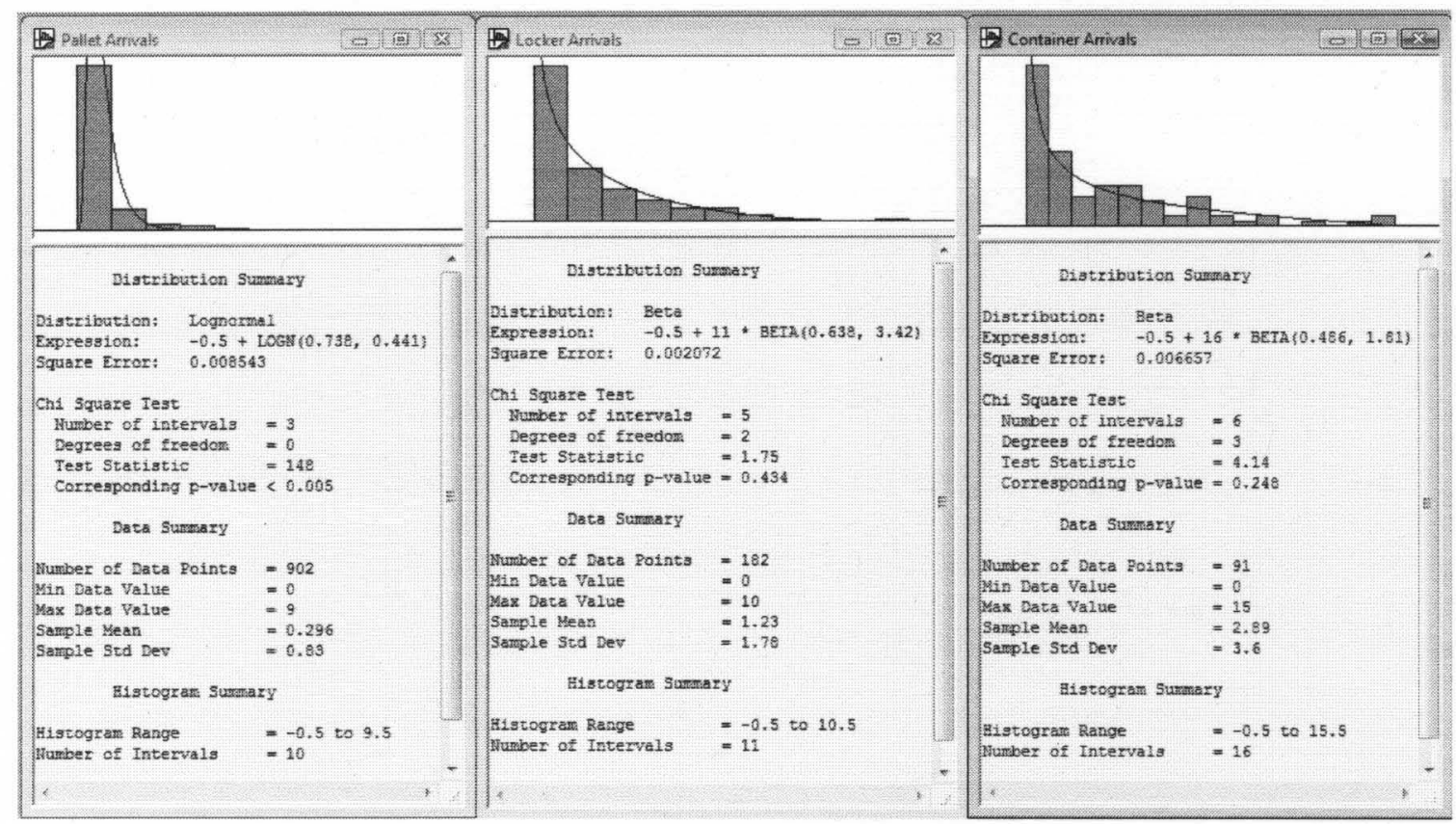

Figure 5 Input Analyzer Outputs

From the Create Modules the color of the paint that is to be applied to the entity is assigned. For the pallets the entities move directly to an Assign Module that assigns the color blue. Lockers are either painted blue or white. A Decide Module, shown in Figure 6, is placed before two Assign Modules where $75 \%$ of the entities passing through it are directed to the blue Assign Module and the rest are sent to the white Assign Module. Containers are painted blue, white or tan and this is also determined with a Decide Module shown in Figure 7. In this module $60 \%$ are sent to be assigned the blue color, $20 \%$ are sent to white and all others are sent to tan.

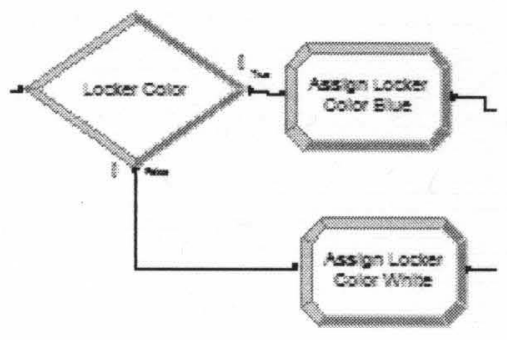

Figure 6 Locker Paint Color Decision 


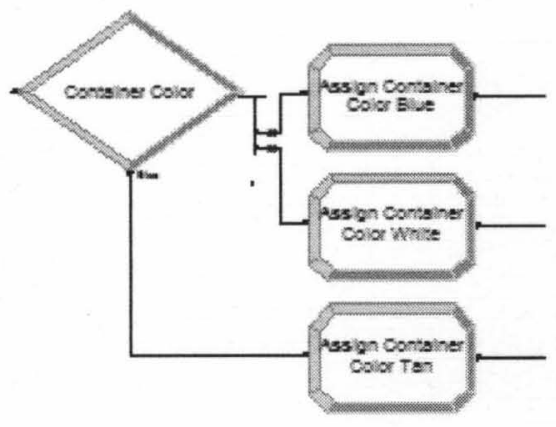

Figure 7 Container Paint Color Decision

After the colors have been decided the pallets and lockers are sent to Batch Modules to group the products so they can be sent into the paint booth at the same time. Pallets batch sizes are set at 10 and lockers are 4. This is shown in Figure 8.
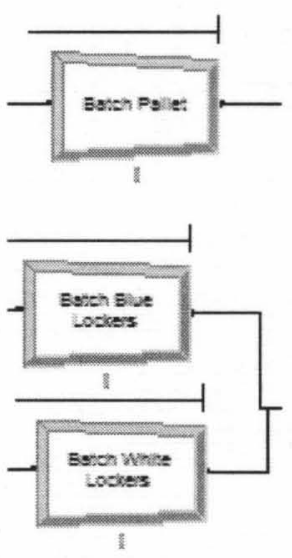

Figure 8 Pallet and Locker Batching

Next, the processes of prepping and painting are modeled. There is a single painting resource that is created in the Arena model in order to process the product lines one at a time. The resource represents the crew of two people in the paint area. There are three parallel sets of modules that represent the painting process and contain the different process times for the products shown in Figure 9. The first module in the line is a Seize Module to obtain the painting resource. The Seize Module for the container queue has a higher priority than the other two lines. From there the batch or entity moves to a Delay Module to represent the amount of time taken to prepare the products to be painted. 
There is an absence of empirical data for these processes. The activity times are based on what is "most likely" to happen with some variation associated with it and therefore use a triangular distribution (Kelton, Sadowski and Swets 2010). The numbers in the equations based on the Operations Manager's expected times in the process where the middle number in the equation is the expected time and the first and third number is the times that bounded time that the process can be no less than or greater than (Woosley 2009). Equation 1 is the expression used as the time a batch of pallets or lockers are prepped in hours. Equation 2 is the expression used for containers as the prep time in hours.

$\operatorname{TRIA}(1,2,2.5)$

$\operatorname{TRIA}(3,4,5)$

After being prepared for paint, the next module is another Delay Module to represent the amount of time the items are spent being painted. Equations 1 and 2 are used again as process times. Equation 1 is the expression used as the time a batch of pallets or lockers are painted in hours. Equation 2 is the expression used for containers as the paint time in hours. After leaving the Delay Modules the painting resource is released.
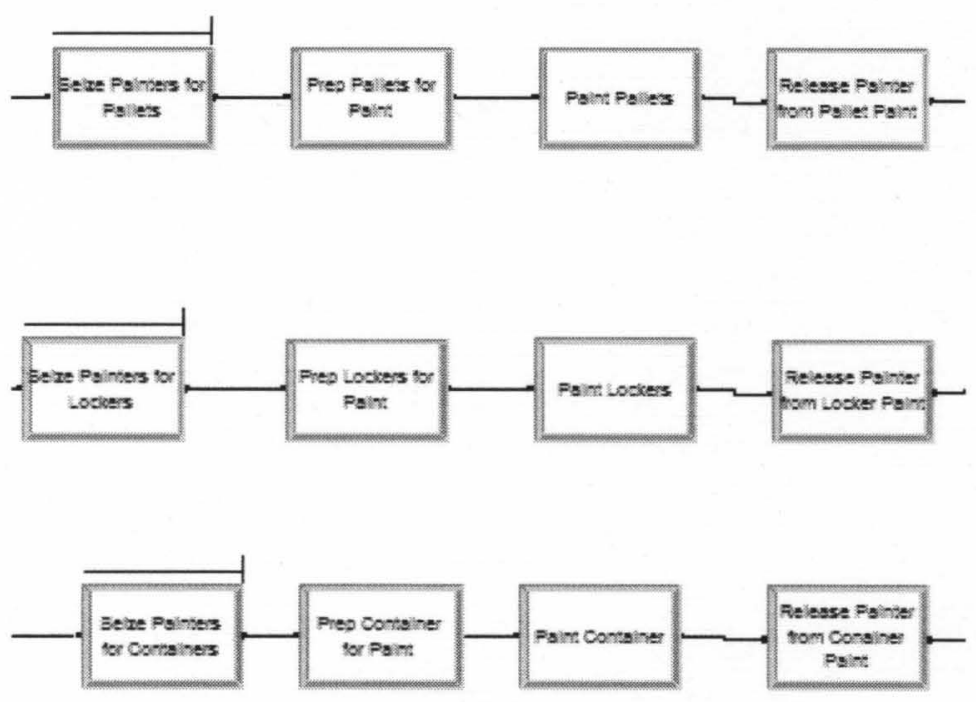

Figure 9 Model of the Painting Process 
After the painting is done batches leaving the locker and pallet process are separated. Then, they are disposed of and leave the model. Painted containers leave straight away. The model of this is shown in Figure 10.
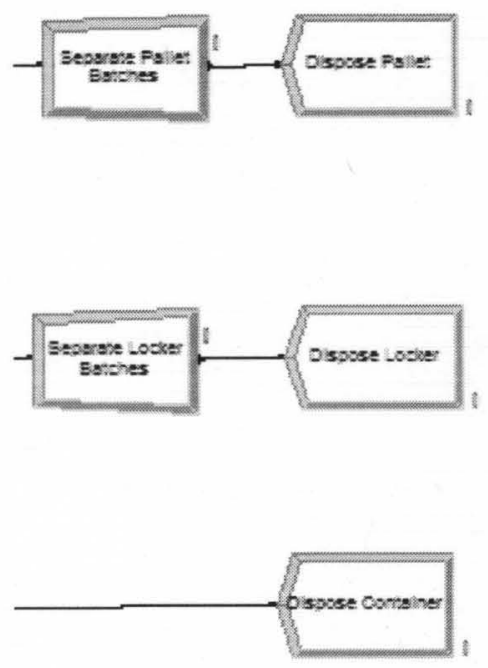

Figure 10 Model of Batches Separating and Disposal

When the model is run, it is set up for 3 replications. The replication length is set to simulate a full working year which is 255 days and there are 8 hours run per day. There is a warm-up period of 5 days in order to run off the effects of the empty model in its initial condition. 


\section{CHAPTER 4. SIMULATION MODEL DEVELOPMENT}

\subsection{Current Model Outputs}

After running the Arena model for the current DENIOS paint process data can be drawn from the report generated. The full report can be found in the appendix.

The main output to look at for this model is the cycle time. This is the average time that an entity will spend in the model for the time it is enters to the time is exits. For this model it equals the amount of time the entity spends waiting in a queue plus the time spent being processed. Table 1 below shows the time that each of the product type spends in the system broken down by its assigned color.

Table 1 DENIOS Current Paint Process Cycle Time Breakdown

\begin{tabular}{|l|c|c|c|c|}
\hline $\begin{array}{c}\text { Product } \\
\text { Type }\end{array}$ & Color & $\begin{array}{c}\text { Queue Wait } \\
\text { Time }\end{array}$ & $\begin{array}{c}\text { Process } \\
\text { Time }\end{array}$ & $\begin{array}{c}\text { Total Cycle } \\
\text { Time }\end{array}$ \\
\hline \hline Pallet & Blue & 1.82 & 0.45 & 2.28 \\
\hline Locker & Blue & 3.69 & 0.46 & 4.15 \\
\hline Locker & White & 7.91 & 0.47 & 8.38 \\
\hline Container & Blue & 0.54 & 1.00 & 1.55 \\
\hline Container & White & 0.46 & 1.01 & 1.47 \\
\hline Container & Tan & 0.60 & 0.99 & 1.59 \\
\hline
\end{tabular}

Time Units: Days

There are a few values in Table 1 that jump out as higher than the others. The locker product group as a whole spends much more time in the system than the other two products. 
Also, white lockers spend over a week in the system. Lower numbers of entities coupled with having to batch these products are leading to higher amounts of time inside the system.

Remember to note that there are fewer numbers of container products than both lockers and pallets but they have a high priority when being seized by the painters. This eliminates large amounts of time waiting in a queue.

\subsection{Locker and Pallet Line Merge}

When it comes to the locker line, the lockers are batched together. However, there are not as many lockers entering the system as the pallet line. This means that lockers wait longer in a queue in order for them to acquire the number needed to form a full batch. The effects of this long waits can be seen in the cycle times being much longer for lockers than either of the two other lines in the current system simulation.

In order to decrease the cycle times, Little's Law one of the four scenarios from the article written by Rust can be used. The idea is to decrease the work in process by having shorter queue lengths in the formulation of the blue locker batch. To execute this, the blue lockers and pallets can be processed at the same time. This will take some work with the paint supplier to find a suitable paint that will meet all the design specifications for both products.

To reflect this change the original simulation is altered slightly. The branch that once went from the Assign Module to the locker Batch Module is redirected to the Batch Module that batched the blue pallets. This Batch Module will not watch blue lockers and pallets together. Due to space restrictions inside the paint booth, the batch size is reduced by two to eight units in order to accommodate the larger locker products. The section of the simulation module that was altered is shown in Figure 11. 


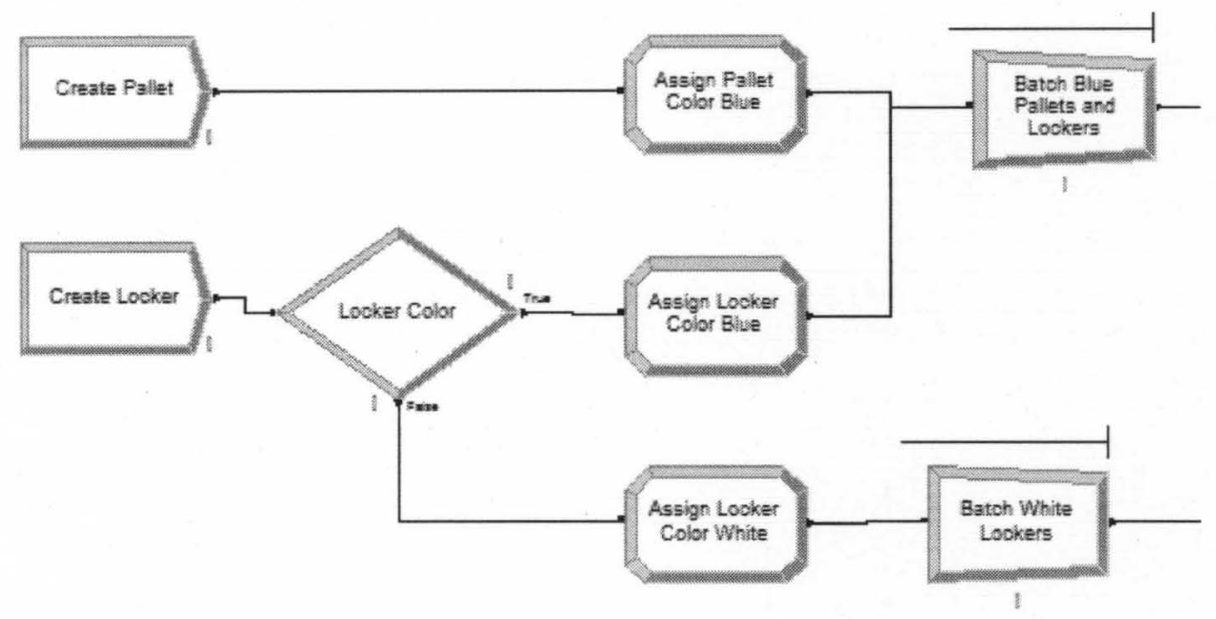

Figure 11 Combining Blue Pallets and Lockers

Also, in order to separately keep track of the number of lockers and pallets that exits the system in the Dispose Modules, a Decide Module is added after the blue pallet and locker batches are separated. The module decides which product type the entity is and directs it towards the appropriate Dispose Module. This is shown in Figure 12.

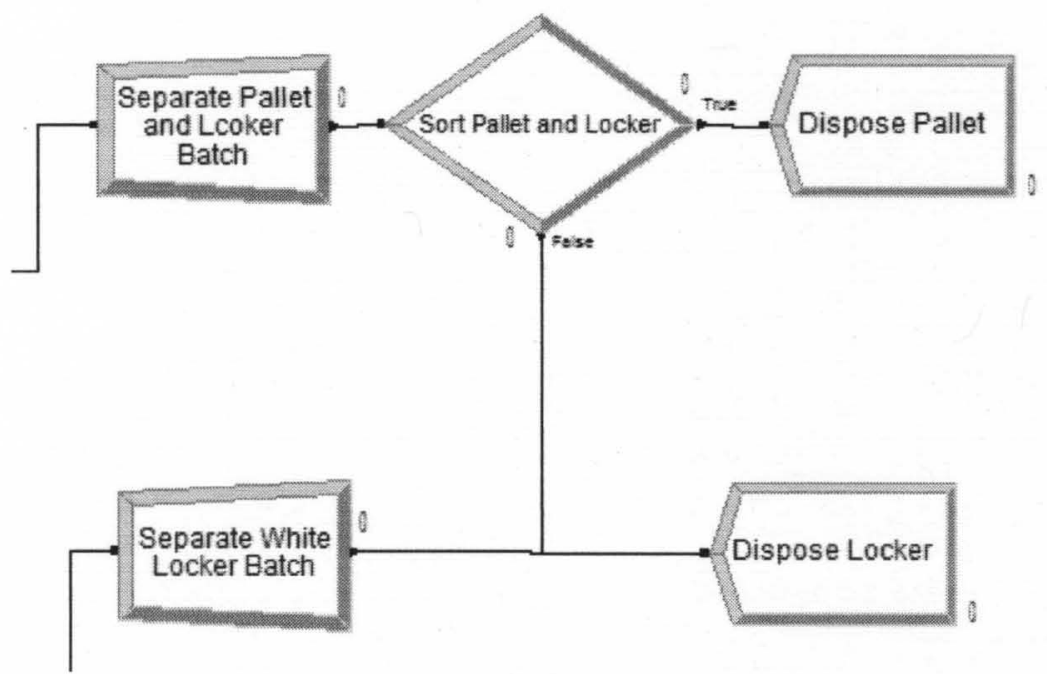

Figure 12 Decide Module to Decide Product Type 


\subsection{Adding Additional Paint Resources}

Another situation in the paint process that can utilize Little's Law is the staging between the pre-paint process and the painting process. Currently there is one resource of a group of workers that prepares the products for paint and then the same group is seized to paint the units. If the company was able to add a few more workers to the paint department there could be another resource added in order to be able to prepare products for paint and be in the act of painting at the same time. Doing so would promote flow in the paint process and reduce the queue lengths. This is will decrease the work in process causing the cycle time for any of the product lines.

To model this first the there needs to be a resource added to the model. In the original model there was a single paint resource. Now, in the modified model there is a pre-paint resource that is to be added. This way there will be the ability for both stages of the paint area to be working at once.

The sequence of modules for the paint process also needs to be altered. First, the initial Seize Module needs to be changed to select the new pre-paint resource. This resource is then released after the Delay Module for the paint preparation process. This sequence will complete the pre-paint process. Next, an additional Seize Module is added to grab the paint resource. This moves onto a Delay Module that has to be added for the paint to be mixed and paint lines to be prepared. Before this process was incorporated into the pre-paint process but since the idea is to have the paint lines in use during this time it is shifted to when the lines are free. A triangular distribution with an expected time of 20 minutes and a minimum and maximum of 15 and 25 minutes respectively is used in this module's delay time. After the paint process module the last thing to do is release the paint resource. This new paint sequence is illustrated in Figure 13 and needs to be applied in all three instances in the model where painting occurs. 


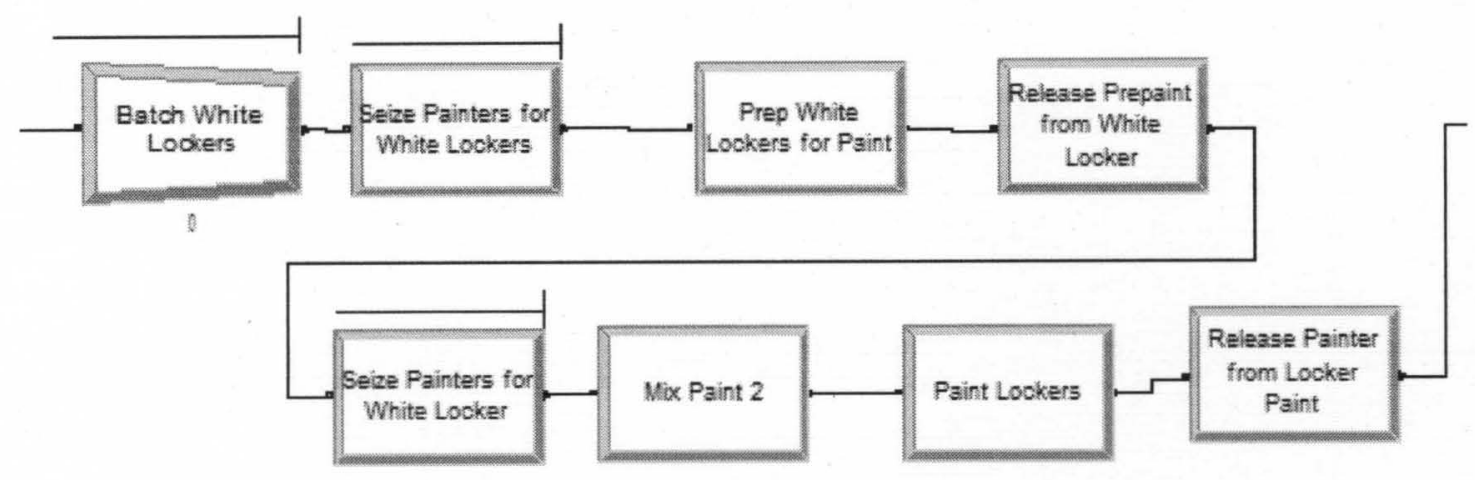

Figure 13 Modified Paint Process with Paint Additional Resources

\subsection{Locker Color Blocking}

Another issue involved with lockers is the two different colors that are applied to the units. The ratio used in the simulation is that there are three blue lockers to every white locker. Again, there concerns with batching these lockers because white lockers will have to wait longer than blue lockers in order to form batched. Currently white lockers are in the system twice as long as the blue ones.

In order to reduce the time that white locker the concept of color blocking from the article "Paint Line Color Change Reduction in Automobile Assembly Through Simulation" was utilized. The idea is that if production can find a way to produce the lockers in such a way that they are released at the same time and have the same color then the waiting time in the queue to be batched will be reduced.

In order to reflect this, a change in the model where lockers are created was made. This change is in Figure 14. 


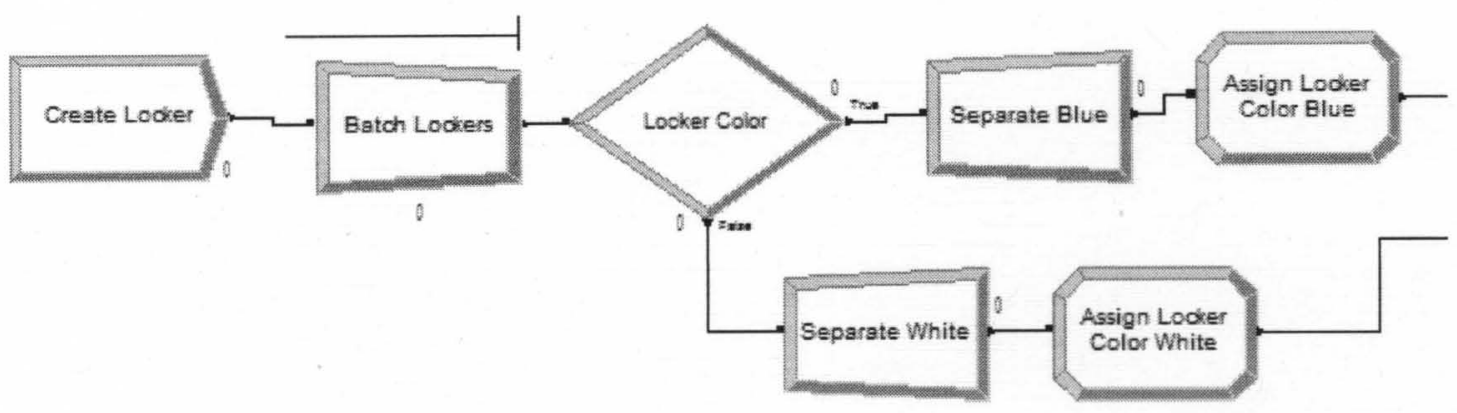

Figure 14 Color Blocking for Lockers

The Create Module for the lockers was altered so that two entities entered the model at the same time. Also, in order to preserve the current product mix in all three product lines, the arrival rate in the Create Module is halved.

Added before the Decide Module, is a Batch Module, which batches the lockers together in the same size as they arrive together. This is done so that the Decide Module does not split up the lockers as it passes through it and will maintain the color block. Once the direction of the lockers is chosen, the batch is split and the color is assigned just as it had been in the original model.

\subsection{Batch Sizes}

Batch sizing is a way that DENIOS can find batch sizes that will help improve the cycle times of their products through the paint department. The Arena program being utilized in this project comes with an application call the Process Analyzer that is capable of creating different scenarios of a simulation model and easily changing variables or controls in the model and giving the resulting responses allowing the user to easily make reliable decisions. This differs from the optimization techniques outlined in the article discussed in the literature review because those methods are solved using algorithms that will solve the problem. 
In order to prepare the simulation model for allowing different batch sizes and still maintaining realistic process times, the Delay Modules that represent work being done to the products needs to be altered. In the first model the process times for the pallets and lockers we based on a batch of a certain size but with varying sizes the process times for processing the batch needs to be able to reflect this. To do this the modules use to prepare the blue pallets and lockers is altered to an equation that is the variable for the batch sized being used multiplied by the distribution of how long it takes to process one unit in units of minutes. This is equation is shown in Equation 5.

. Blue Pallet and Locker Batch * TRIA( 17, 22, 30)

Similarly, the process time for the white lockers being painted is the variable multiplied by the distribution of how long it takes to process one unit in units of minutes.

White Locker Batch*TRIA( 17, 22,30 )

In the new modified paint process there are two batches that need to be analyzed, which will be the controls of the input analyzer, the blue pallet and locker batch and the white pallet batch size. The batch sizes that can be chosen for the blue paint products were to be looked at for batches of between 8 and 2 units. White lockers are going to be entered as between two and four. The best batch size is expected to be smaller due to lower arrival rates white lockers. The responses of each scenario are the total times that each product spends in the system. Each combination of batch size is used and the original model is included as a base line to see how much of an improvement there is.

When the analyzer is ran the responses of each scenario is generated and conclusions can be draw. Table 2 displays the resulting scenarios of the different batch sizes. 
Based on the results it appears that having the white locker line with a batch size of two

will yield the quickest cycle times for that product. Looking at the blue pallets and lockers a

batch size of three and five units in a batch yields around just over a one day cycle time. Though

it doesn't appear to have much of a difference than four and five units, a batch size of three units has the lowest cycle time.

Table 2 Process Analyzer Results for Different Batch Sizes

\begin{tabular}{|c|c|c|c|c|c|c|c|c|}
\hline & \multicolumn{2}{|c|}{ Batch Size } & \multicolumn{6}{|c|}{ Total Time } \\
\hline & $\begin{array}{c}\text { Blue } \\
\text { Pallet/Locker }\end{array}$ & $\begin{array}{l}\text { White } \\
\text { Locker }\end{array}$ & $\begin{array}{l}\text { Biue } \\
\text { Pallet }\end{array}$ & $\begin{array}{c}\text { Blue } \\
\text { Locker }\end{array}$ & $\begin{array}{l}\text { White } \\
\text { Locker }\end{array}$ & $\begin{array}{c}\text { Blue } \\
\text { Container }\end{array}$ & $\begin{array}{c}\text { White } \\
\text { Container }\end{array}$ & $\begin{array}{c}\text { Tan } \\
\text { Container }\end{array}$ \\
\hline Original Model & --- & -- & 2.28 & 4.15 & 8.38 & 1.55 & 1.47 & 1.59 \\
\hline Base Case & 8 & 2 & 1.56 & 1.45 & 0.76 & 1.30 & 1.20 & 1.34 \\
\hline Case 1 & 7 & 2 & 1.40 & 1.26 & 0.84 & 1.30 & 1.42 & 1.18 \\
\hline Case 2 & 6 & 2 & 1.36 & 1.38 & 0.83 & 1.36 & 1.36 & 1.26 \\
\hline Case 3 & 5 & 2 & 1.16 & 1.08 & 0.79 & 1.27 & 1.26 & 1.22 \\
\hline Case 4 & 4 & 2 & 1.12 & 1.16 & 0.89 & 1.38 & 1.25 & 1.23 \\
\hline Case 5 & 3 & 2 & 1.10 & 1.15 & 0.93 & 1.36 & 1.32 & 1.39 \\
\hline Case 6 & 2 & 2 & 1.51 & 1.48 & 1.43 & 1.53 & 1.48 & 1.57 \\
\hline Case 7 & 8 & 3 & 1.61 & 3.88 & 3.39 & 1.29 & 1.27 & 1.30 \\
\hline Case 8 & 7 & 3 & 1.58 & 3.57 & 3.19 & 1.38 & 1.28 & 1.28 \\
\hline Case 9 & 6 & 3 & 1.36 & 2.90 & 3.32 & 1.25 & 1.28 & 1.27 \\
\hline Case 10 & 5 & 3 & 1.20 & 3.66 & 2.79 & 1.25 & 1.31 & 1.31 \\
\hline Case 11 & 4 & 3 & 1.19 & 3.70 & 3.31 & 1.38 & 1.43 & 1.28 \\
\hline Case 12 & 3 & 3 & 1.15 & 3.44 & 3.66 & 1.36 & 1.32 & 1.38 \\
\hline Case 13 & 2 & 3 & 1.47 & 3.34 & 4.04 & 1.50 & 1.41 & 1.51 \\
\hline Case 14 & 8 & 4 & 1.56 & 3.56 & 1.83 & 1.38 & 1.20 & 1.27 \\
\hline Case 15 & 7 & 4 & 1.51 & 4.00 & 3.64 & 1.27 & 1.40 & 1.40 \\
\hline Case 16 & 6 & 4 & 1.39 & 4.36 & 3.18 & 1.44 & 1.34 & 1.29 \\
\hline Case 17 & 5 & 4 & 1.26 & 3.68 & 3.19 & 1.35 & 1.22 & 1.43 \\
\hline Case 18 & 4 & 4 & 1.22 & 4.55 & 4.22 & 1.42 & 1.43 & 1.35 \\
\hline Case 19 & 3 & 4 & 1.25 & 3.84 & 8.35 & 1.51 & 1.39 & 1.33 \\
\hline Case 20 & 2 & 4 & 1.33 & 4.43 & 5.23 & 1.53 & 1.52 & 1.43 \\
\hline
\end{tabular}




\subsection{New Model Output}

After taking all the new concepts learned in the previous four sections and applying them to the simulation model for the paint process and DENIOS, an overview of the modified model is shown in Figure 15.

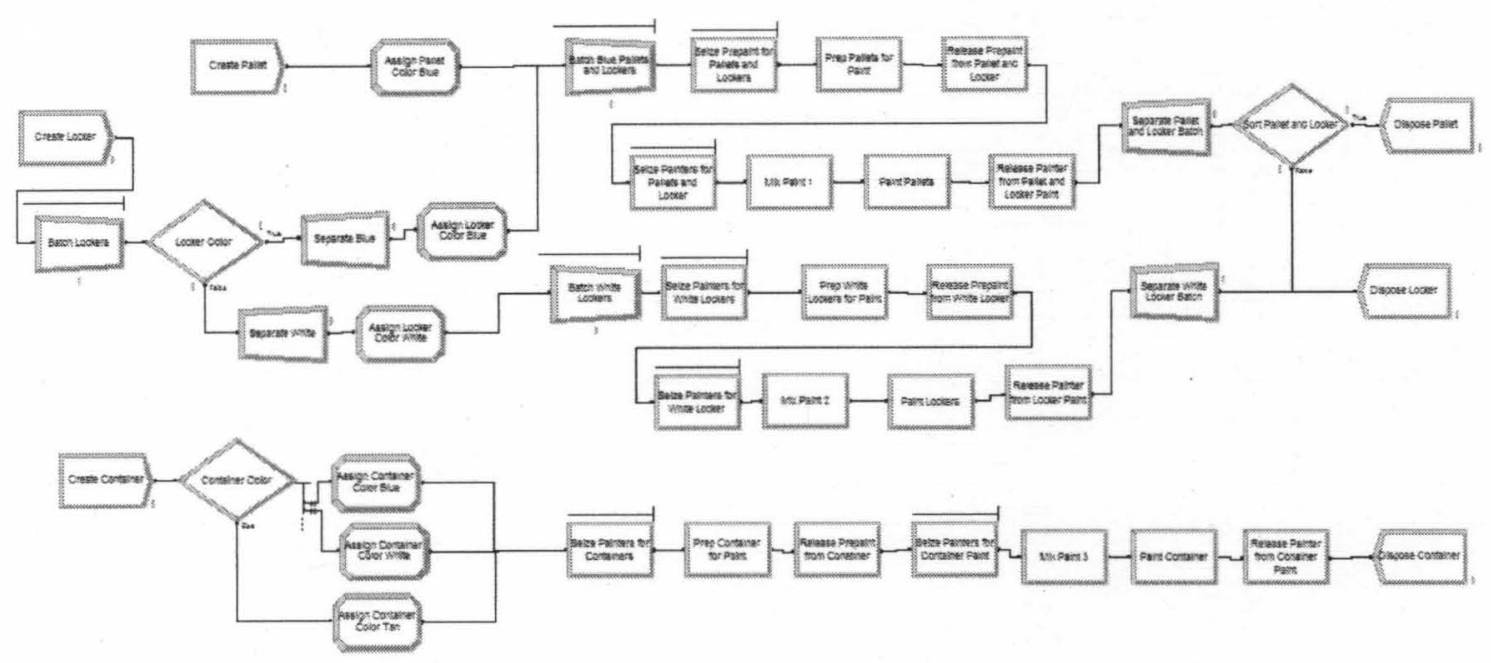

Figure 15 Overview of the Modified DENIOS Paint Process

The run parameters for the simulation are the same as before. When the model is run, it is set up for 3 replications. The replication length is set to simulate a full working year which is 255 days and there are 8 hours run per day. There is a warm-up period of 5 days in order to run off the effects of the empty model in its initial condition.

When the model is run the cycle time results of this new model are show in Table 3. 
Table 3 Modified Paint Process Results

\begin{tabular}{|l|c|c|c|c|}
\hline $\begin{array}{c}\text { Product } \\
\text { Type }\end{array}$ & Color & $\begin{array}{c}\text { Queue Wait } \\
\text { Time }\end{array}$ & $\begin{array}{c}\text { Process } \\
\text { Time }\end{array}$ & $\begin{array}{c}\text { Total Cycle } \\
\text { Time }\end{array}$ \\
\hline \hline Pallet & Blue & 0.53 & 0.33 & 0.86 \\
\hline Locker & Blue & 0.62 & 0.32 & 0.94 \\
\hline Locker & White & 0.36 & 0.23 & 0.60 \\
\hline Container & Blue & 0.25 & 1.04 & 1.29 \\
\hline Container & White & 0.26 & 1.04 & 1.30 \\
\hline Container & Tan & 0.29 & 1.05 & 1.33 \\
\hline
\end{tabular}

Time Units: Days 


\section{CHAPTER 5. CONCLUSIONS AND FURTHER RESEARCH}

\subsection{Conclusions}

Looking at the results of the new model and results of the current process DENIOS is using to paint its products it can be seen that the changes can help. Table 4 shows how much of a change is made.

Table 4 Cycle Time Comparisons of Two Models

\begin{tabular}{|l|c|c|c|c|}
\hline $\begin{array}{c}\text { Product } \\
\text { Type }\end{array}$ & Color & $\begin{array}{c}\text { Current } \\
\text { Total Cycle } \\
\text { Time }\end{array}$ & $\begin{array}{c}\text { New } \\
\text { Model } \\
\text { Total Cycle } \\
\text { Time }\end{array}$ & $\begin{array}{c}\% \\
\text { Improvement }\end{array}$ \\
\hline \hline Pallet & Blue & 2.28 & 0.86 & 62 \\
\hline Locker & Blue & 4.15 & 0.94 & 77 \\
\hline Locker & White & 8.38 & 0.60 & 93 \\
\hline Container & Blue & 1.55 & 1.29 & 17 \\
\hline Container & White & 1.47 & 1.30 & 11 \\
\hline Container & Tan & 1.59 & 1.33 & 16 \\
\hline
\end{tabular}

Due to the effects of the process changes there are staggering positive effects in the cycle times for both the pallet and locker lines. The time that units have to spend waiting to be processed decreased drastically.

There was minimal change in the cycle times of the container products. These models were always moved through the system with minimal waiting times. The changes to the simulation model helped these products minimally by reducing the chances that the paint 
resources would be in use processing pallets and lockers and thus reducing the chances of having to wait in a queue to be processed.

It is recommended that for DENIOS to decrease its cycle time for the products being processed in this paint area it execute the following steps:

1. When scheduling lockers it is best to release lockers into production in such a way that they arrive to the paint department in pairs of two. This way the method of color blocking can reduce waiting times for white lockers.

2. To aid in the reduction of waiting times for blue lockers, the company should find a way to purchase a blue coating that will be sufficient to be used on both pallets and blue lockers. This way they can be selected for processing in the same batch and reduce waiting times.

3. The company should consider the addition of man power in the paint department in order to have resources working to prepare units for paint and to be painting units simultaneously.

4. The company should reduce the number of pallets and lockers that it batches to be processed. The mindset that the paint booth must be filled to capacity to be in use is inefficient.

Implementing these changes will go a long way for the company. First, the work in process in the paint department will be reduced. This means that less floor space will be taken up to store units waiting to be processed. The company will serve the customers better by being able to offer shorter lead times on delivery. Better delivery forecasts can be made due to shorter lead times keeping the customers satisfied and the company can have an edge over its competitors.

\subsection{Further Research}


The reason for the research in this paper was driven by the potential for DENIOS to grow its production capabilities in the future. Since it is difficult to tell what the future holds the company must remain active in analyzing its processes. The product mix being and increasing number of units sent through the paint department can easily change due to customer demands or business models changing. These changes can affect the results of the research found here and cycle times can change and batch sizes that were found to be good solutions will become outdated. Keeping up with these changes will ensure that the company maintains short cycle times in the paint department. 


\section{REFERENCES}

Han, Yong- Hee, Chen Zhou, Bert Bras, Leon McGinnis, Carol Carmichael, and PJ Newcomb. "Paint Line Color Change Reduciton in Automobile Assembly Through Simulation." Winter Simulation Conference. 2003. 1204-1209.

Heizer, Jay, and Barry Render. "Operation Managment." 606-607, 795-796. River, New Jersey: Pearson Prentice Hall, 2006.

Hopp, Wallace J., and Mark L. Spearman. "Factory Physics." 518-519. New York: McGraw-Hill, 2008.

Kelton, W, R Sadowski, and N Swets. "Simulation With Arena." 178-199. New York: McGrawHill, 2010.

Klemmt, Andreas, Sven Horn, Gerald Weigert, and Thomas Hielscher. "Simulations-Based and Solver-Based Optimization Approaches for Batch Processes In Semiconductor Manufacturing." Winter Simulation Conference. 2008. 2041-2049.

Rust, Kristen. "Using Little's Law to Esimate Cycle Time and Cost." Winter Simulaiton Confernce. 2008. 2223-2228.

Standridge, Charles R. "How Factory Physics Helps Simulation." Winter Simulation Conference. 2004. 1103-1108.

Womack, James, and Daniel Jones. "Lean Thinking." 50-51. New York: Free Press, 2003. 
Woosley, Doug, interview by Paul-Victor Heitz. DENIOS Operations Manager (March 27, 2009). 


\section{APPENDIX}

\section{Arena Output for Current Paint Process}

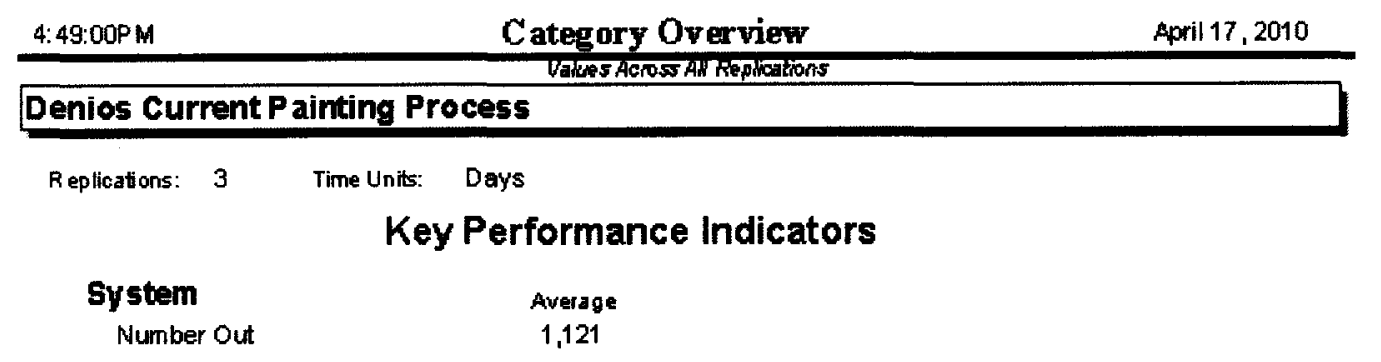

Model Filenarne: C:USerstPWD ocument W of LYE690-ThesisiCurrent ModeKPaint Process Curl Page $1 \quad$ of 6 


\section{Denios Current $P$ ainting Process}

Replications: 3 Time Units: Days

\section{Entity}

Time

\begin{tabular}{|c|c|c|c|c|c|c|}
\hline VA Time & Anerage & Half Width & $\begin{array}{l}\text { Minimum } \\
\text { Aarerage }\end{array}$ & $\begin{array}{l}\text { Maximum } \\
\text { Anverage }\end{array}$ & $\begin{array}{l}\text { Minimum } \\
\text { value }\end{array}$ & $\begin{array}{l}\text { Meximum } \\
\text { Value }\end{array}$ \\
\hline Blue Paint Container & 0.00 & 0.00 & 0.00 & 0.00 & 0.00 & 0.00 \\
\hline Blue Paint Locker & 0.00 & 0.00 & 0,00 & 0.00 & 0.00 & 0.00 \\
\hline Blue $P$ aint $P$ allet & 0.00 & 0.00 & 0.00 & 0.00 & 0.00 & $0 . \infty$ \\
\hline Tan $P$ aint $C$ ontainer & 0.00 & 0.00 & 0.00 & 0.00 & 0.00 & 0.00 \\
\hline W' hite $P$ aint Container & 0.00 & 0.00 & 0.00 & 0.00 & 0.00 & 0.00 \\
\hline White Paint Locker & 0.00 & 0.00 & 000 & 0.00 & 0.00 & $0 . \infty 0$ \\
\hline NWA Time & Awerage & Half width & $\begin{array}{c}\text { Minimum } \\
\text { Average }\end{array}$ & $\begin{array}{c}\text { Maximum } \\
\text { Annerage }\end{array}$ & $\begin{array}{c}\text { Minimum } \\
\text { Value }\end{array}$ & $\begin{array}{l}\text { Maximum } \\
\text { Value }\end{array}$ \\
\hline Blue Paint Container & 0.00 & 0.00 & 0.00 & 0.00 & 0.00 & 0.0 \\
\hline Blue $\mathrm{Paint}$ Locker & 0.00 & 0.00 & 0.00 & 0.00 & 0.00 & 0.00 \\
\hline Blue Paint Pallet & 0.00 & 0.00 & 000 & 0.00 & 0.00 & $0 . \infty$ \\
\hline Tan $P$ aint $C$ ontainer & 0.00 & 0.00 & 0.00 & 0.00 & 0.00 & 0.00 \\
\hline Wh hite $P$ aint Container & 0.00 & 0.00 & 0.00 & 0.00 & 0.00 & 0.00 \\
\hline White Paint Loker & 0.00 & 0.00 & 0.00 & 0.00 & 0.00 & 0.00 \\
\hline Wait Time & Anerage & Half Wuidth & $\begin{array}{c}\text { Minimum } \\
\text { Average }\end{array}$ & $\begin{array}{c}\text { Maximum } \\
\text { Average }\end{array}$ & $\begin{array}{c}\text { Minimum } \\
\text { Value }\end{array}$ & $\begin{array}{l}\text { Meximum } \\
\text { value }\end{array}$ \\
\hline Blue Paint Container & 0.5429 & $\overline{0.25}$ & 0.4316 & 0.6271 & 0.00 & $\overline{32662}$ \\
\hline Blue Paint Lodker & 3.6897 & 0.22 & 3.6219 & 3.7893 & 0.00 & 17.6372 \\
\hline Blue $P$ aint $P$ allet & 1.8241 & 0.46 & 1.7010 & 2.0386 & 0.00 & 8.7058 \\
\hline Tan $P$ aint $C$ ontainer & 0.5978 & 0.70 & 0.2907 & 0.8393 & 0.00 & 3.0937 \\
\hline Wh hite $P$ aint Container & 0.4614 & 0.21 & 0.3788 & 0.5450 & 0.00 & 2.7917 \\
\hline White Paint Locker & 7.9145 & 2.97 & 6.5678 & 8.8576 & 0.00 & 288349 \\
\hline Transfer Time & Auerage & Half Width & $\begin{array}{c}\text { Minimum } \\
\text { Average }\end{array}$ & $\begin{array}{c}\text { Mlaximum } \\
\text { Awerage }\end{array}$ & $\begin{array}{c}\text { Minimum } \\
\text { Value }\end{array}$ & $\begin{array}{l}\text { Maximum } \\
\text { value }\end{array}$ \\
\hline Blue $P$ aint Container & 0.00 & 0.00 & 000 & 0.00 & 0.00 & 0.00 \\
\hline Blue Paint Lodker & 0.00 & 0.00 & 0.00 & 0.00 & 0.00 & 0.00 \\
\hline Blue $P$ aint $P$ allet & 0.00 & 0.00 & 000 & 0.00 & 0.00 & 0.00 \\
\hline Tan $P$ aint $C$ ontainer & 0.00 & 0.00 & 0.00 & 0.00 & 0.00 & 0.00 \\
\hline Wh hite Paint Container & 0.00 & 0.00 & 0.00 & 0.00 & 0.00 & 0.00 \\
\hline White $P$ aint Lodker & 0.00 & 0.00 & 0.00 & 0.00 & 0.00 & 0.00 \\
\hline
\end{tabular}




\section{Denios Current $P$ ainting Process}

Replications: 3 Time Units: Days

Entity

Time

\begin{tabular}{|c|c|c|c|c|c|c|}
\hline Other Time & Awerage & Half Winth & $\begin{array}{l}\text { Minirmum } \\
\text { Aurerage }\end{array}$ & $\begin{array}{l}\text { Maximum } \\
\text { Aunerage }\end{array}$ & $\begin{array}{l}\text { Minimum } \\
\text { Value }\end{array}$ & $\begin{array}{l}\text { Maximum } \\
\text { value }\end{array}$ \\
\hline Glue Paint Container & 1.0044 & 0.01 & 0.9975 & 1.0089 & 0.8381 & 1.1948 \\
\hline Blue Paint Lodker & 0.4689 & 0.02 & 0.4607 & 0.4863 & 0.2888 & 0.5943 \\
\hline Blue Paint Pallet & 0.4549 & 0.01 & 0.4607 & 0.4681 & 0.3174 & 0.5752 \\
\hline Tan $P$ aint $C$ ontainer & 0.9929 & 0.03 & 0.9815 & 1.0082 & 0.8145 & 1.1262 \\
\hline Whithe Paint Container & 1.0050 & 0.06 & 0.9842 & 1.0339 & 0.8423 & 1.1332 \\
\hline White Paint Locker & 0.4671 & 0.03 & 0.4568 & 0.4828 & 0.3121 & 0.5546 \\
\hline Total Time & Anerage & Half Wuidth & $\begin{array}{l}\text { Muinirmum } \\
\text { Anverage }\end{array}$ & $\begin{array}{l}\text { Mtaximum } \\
\text { Awerage }\end{array}$ & $\begin{array}{c}\text { Minimum } \\
\text { value }\end{array}$ & $\begin{array}{l}\text { Maximum } \\
\text { Value }\end{array}$ \\
\hline Blue Paint Container & 1.5472 & 0.26 & 1.4291 & 1.6360 & 0.8381 & 4,3131 \\
\hline Blue Paint Lodker & 4.1487 & 0.23 & 4.0817 & 4.2550 & 0.3628 & 18.1460 \\
\hline Blue $P$ aint $P$ allet & 2.2791 & 0.47 & 2.1517 & 2.4946 & 0.3333 & 92205 \\
\hline Tan $P$ aint $C$ ontainer & 1.5907 & 0.69 & 1.2817 & 1.8207 & 0.8560 & 4.1362 \\
\hline W' hite Paint Container & 1.4604 & 0.23 & 1.3030 & 1.5420 & 0.8583 & 3.6750 \\
\hline W' hite $P$ aint Lodker & 8.3816 & 3.00 & 7.0236 & 9.3404 & 0.3121 & 29.3075 \\
\hline
\end{tabular}

Other 


\section{Denios Current $P$ ainting Process}

Replications: 3 Time Unit: Days

Entity

\section{Other}

\begin{tabular}{lrrrr} 
N umber In & Aderage & Half Width & $\begin{array}{r}\text { Minimum } \\
\text { Awerage }\end{array}$ & $\begin{array}{r}\text { Maximum } \\
\text { Aurerage }\end{array}$ \\
\hline Blue Paint Container & 41.3333 & 12.25 & 38.0000 & 47.0000 \\
Blue Paint Locker & 155.00 & 16.29 & 149.00 & 162.00 \\
Blue Paint Pallet & 964.00 & 68.71 & 935.00 & 988.00 \\
Container & 74.3333 & 15.18 & 69.0000 & 81.0000 \\
Locker & 168.67 & 39.46 & 159.00 & 187.00 \\
Pallet & 876.67 & 61.58 & 850.00 & 899.00 \\
Tan Paint C ontainer & 13.0000 & 7.45 & 10.0000 & 16.0000 \\
White Paint Container & 20.0000 & 13.15 & 14.0000 & 24.0000 \\
White Paint Locker & 55.6607 & 33.82 & 45.0000 & 71.0000
\end{tabular}

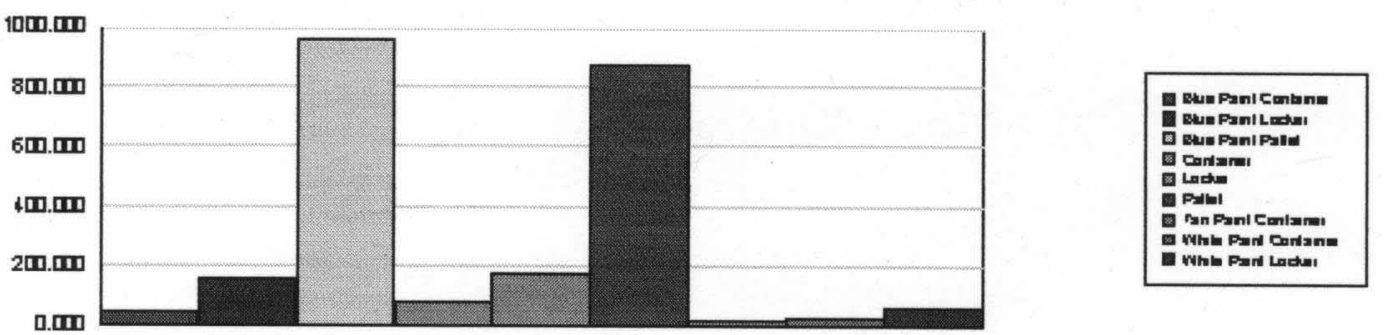

\begin{tabular}{|c|c|c|c|c|}
\hline Number Out & Anerage & Half Winth & $\begin{array}{l}\text { Minimum } \\
\text { Aaverage }\end{array}$ & $\begin{array}{l}\text { Maximum } \\
\text { Aunerage }\end{array}$ \\
\hline Blue Paint Container & 42.0000 & 10.83 & 39.0000 & 47.0000 \\
\hline Blue Paint Locker & 156.67 & 18.97 & 150.00 & 165.00 \\
\hline Blue $P$ aint $P$ allet & 984.33 & 68.77 & 935.00 & 990.00 \\
\hline Container & 74.3333 & 15.18 & 69.0000 & 81.0000 \\
\hline Locker & 168.67 & 39.46 & 159.00 & 187.00 \\
\hline Pallet & 876.67 & 61.58 & 850.00 & 899.00 \\
\hline Tan $P$ aint $C$ ontainer & 13.0000 & 7.45 & 10.0000 & 16.0000 \\
\hline Withite $P$ aint Container & 20.0000 & 13.15 & 14.0000 & 24.0000 \\
\hline Wu'hite Paint Locker & 55.0000 & 32.86 & 45.0000 & 70.0000 \\
\hline
\end{tabular}

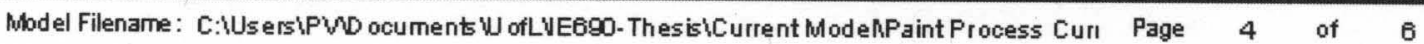




\section{Denios Current $P$ ainting Process}

Replications: 3 Time Unit: Days

\section{Entity}

\section{Other}

\begin{tabular}{|c|c|c|c|c|c|c|}
\hline W'IP & Anerage & Half Whifith & $\begin{array}{l}\text { Minimum } \\
\text { Awerage }\end{array}$ & $\begin{array}{c}\text { Maximum } \\
\text { Anverage }\end{array}$ & $\begin{array}{l}\text { Minimum } \\
\text { Value }\end{array}$ & $\begin{array}{l}\text { Naximum } \\
\text { Value }\end{array}$ \\
\hline Blue Paint Container & 0.2544 & 0.11 & 0.2115 & 0.2964 & 0.00 & 40000 \\
\hline Blue Paint Lodker & 2.2103 & 0.18 & 2.1528 & 2.2923 & 0.00 & 10,0000 \\
\hline Blue $P$ aint $P$ allet & 8.3349 & 1.97 & 7.7179 & 9.2266 & 0.00 & 490000 \\
\hline Container & 0.00 & 0.00 & 000 & 0.00 & 0.00 & 10000 \\
\hline Locker & 0.00 & 0.00 & 0,00 & 0.00 & 0.00 & 10000 \\
\hline Pallet & 0.00 & 0.00 & 0.00 & 0.00 & 0.00 & 10000 \\
\hline Tan Paint $C$ ontainer & 0.08487245 & 0.08 & 0.05126940 & 0.1165 & 0.00 & 30000 \\
\hline White $P$ aint Container & 0.1172 & 0.08 & 0.00367837 & 0.1480 & 0.00 & 20000 \\
\hline W' hite P aint Lodker & 1.5573 & 0.43 & 1.4505 & 1.7548 & 0.00 & 8.0000 \\
\hline
\end{tabular}

\section{Queue}

\section{Time}

\begin{tabular}{|c|c|c|c|c|c|c|}
\hline Wvating Time & Aaerage & Half Wuldth & $\begin{array}{l}\text { Minimum } \\
\text { Average }\end{array}$ & $\begin{array}{l}\text { Maximum } \\
\text { Aperage }\end{array}$ & $\begin{array}{c}\text { Minimum } \\
\text { Value }\end{array}$ & $\begin{array}{c}\text { Maxirnum } \\
\text { Value }\end{array}$ \\
\hline Batch Blue Lockers.Queve & 3.0226 & 0.37 & 2.8777 & 3.1740 & 0.00 & 176372 \\
\hline Batch Pallet.Queue & 1.2904 & 0.17 & 1.2376 & 1.3668 & 0.00 & 0.1698 \\
\hline Batch White Lockers.Queve & 7.0882 & 2.41 & 5.9827 & 7.7873 & 0.00 & 288349 \\
\hline $\begin{array}{l}\text { Seize Painters for } \\
\text { Containers.Queue }\end{array}$ & 0.5389 & 0.24 & 0.4463 & 0.8425 & 0.00 & 32602 \\
\hline $\begin{array}{l}\text { Seize Painters for } \\
\text { Lockers.Queue }\end{array}$ & 0.7084 & 0.09 & 0.6673 & 0.7382 & 0.00 & 48548 \\
\hline $\begin{array}{l}\text { Seize Painters for } \\
\text { Pallets.Queue }\end{array}$ & 0.5344 & 0.53 & 0.3601 & 0.718 & 0.00 & 60452 \\
\hline
\end{tabular}

\section{Other}

\begin{tabular}{|c|c|c|c|c|c|c|}
\hline Number wir aiting & Average & Half wioth & $\begin{array}{l}\text { Minimum } \\
\text { Average }\end{array}$ & $\begin{array}{l}\text { Maximum } \\
\text { Average }\end{array}$ & $\begin{array}{l}\text { Minimum } \\
\text { value }\end{array}$ & $\begin{array}{l}\text { Mtaximum } \\
\text { value }\end{array}$ \\
\hline Batch Blue Lockers.Queve & 1.5045 & 0.01 & 1.5012 & 1.5084 & 0.00 & 40000 \\
\hline Batch Pallet.Queve & 4.5207 & 0.25 & 4.4540 & 4.6355 & 0.00 & 100000 \\
\hline Batch White Lockers.Queve & 1.2812 & 0.39 & 1.1710 & 1.4634 & 0.00 & 40000 \\
\hline Pre Paint Prep Pallets.Queve & 0.00 & 0.00 & 000 & 0.00 & 0.00 & 0.00 \\
\hline $\begin{array}{l}\text { Seize Painters for } \\
\text { Containers. Queve }\end{array}$ & 0.1573 & 0.07 & 0.1235 & 0.1773 & 0.00 & 40000 \\
\hline $\begin{array}{l}\text { Seize Painters for } \\
\text { Lockers Queue }\end{array}$ & 0.1187 & 0.03 & 0.1068 & 0.1313 & 0.00 & 30000 \\
\hline $\begin{array}{l}\text { Seize Painte is for } \\
\text { Pallets.Queue }\end{array}$ & 0.1873 & 0.19 & 0.1245 & 0.2717 & 0.00 & 40000 \\
\hline
\end{tabular}




\section{Denios Current $P$ ainting Process}

Replications: 3 Time Units: Days

\section{Resource}

\section{Usage}

\begin{tabular}{|c|c|c|c|c|c|c|}
\hline Instantaneous Utilization & Auerage & Half Wuidith & $\begin{array}{l}\text { Minimum } \\
\text { Auserage }\end{array}$ & $\begin{array}{c}\text { Maximum } \\
\text { Annerage }\end{array}$ & $\begin{array}{l}\text { Mulinimum } \\
\text { Walue }\end{array}$ & $\begin{array}{l}\text { Maximum } \\
\text { Value }\end{array}$ \\
\hline Paint & 0.5303 & 0.05 & 0.5238 & 0.5013 & 0.00 & 10000 \\
\hline Number Busy & Anerage & Half untidth & $\begin{array}{l}\text { Minimum } \\
\text { Average }\end{array}$ & $\begin{array}{c}\text { Maximum } \\
\text { Amarage }\end{array}$ & $\begin{array}{l}\text { Minimum } \\
\text { Value }\end{array}$ & $\begin{array}{l}\text { haximum } \\
\text { Value }\end{array}$ \\
\hline Paint & 0.5383 & 0.05 & 0.5238 & 0.5613 & 0.00 & 10000 \\
\hline Number Scheduled & Awerage & Half Whitth & $\begin{array}{l}\text { Minirrum } \\
\text { Average }\end{array}$ & $\begin{array}{l}\text { Mtaximum } \\
\text { Awerage }\end{array}$ & $\begin{array}{l}\text { Minimum } \\
\text { Value }\end{array}$ & $\begin{array}{l}\text { haximum } \\
\text { value }\end{array}$ \\
\hline Paint & 1.0000 & 0.00 & 1.0000 & 1.0000 & 1.0000 & 10000 \\
\hline Scheduled Utilization & Awerage & Half halith & $\begin{array}{l}\text { Minimum } \\
\text { Average }\end{array}$ & $\begin{array}{c}\text { Maximum } \\
\text { Awerage }\end{array}$ & & \\
\hline Paint & 0.5363 & 0.05 & 0.5238 & 0.5613 & & \\
\hline Total Number Seized & Anerage & Half Whidth & $\begin{array}{l}\text { Minimum } \\
\text { Anserage }\end{array}$ & $\begin{array}{c}\text { Maximum } \\
\text { Aarerage }\end{array}$ & & \\
\hline Paint & 204.00 & 13.93 & 198.00 & 210.00 & & \\
\hline
\end{tabular}




\section{Arena Output for Modified Paint Process}

12:08:33AM $\quad$ Category Overview

April 23, 2010 Valkes ACross All Rephotions

Denios Current $P$ ainting Process

Replications: $\quad 3$

Time Units: Days

Key Performance Indicators

System

Number Out

Average

1,195 


\section{Denios Current $P$ ainting Process}

Replications: 3 Time Units: Days

\section{Entity}

\section{Time}

\begin{tabular}{|c|c|c|c|c|c|c|}
\hline VA Time & Anerage & Half tulodth & $\begin{array}{l}\text { Minimum } \\
\text { Aarerage }\end{array}$ & $\begin{array}{c}\text { Maximum } \\
\text { Avnerage }\end{array}$ & $\begin{array}{l}\text { Minimum } \\
\text { Walue }\end{array}$ & $\begin{array}{l}\text { Maximum } \\
\text { Value }\end{array}$ \\
\hline Olue $P$ aint Containet & 0.5008 & 0.02 & 0.4933 & 0.6059 & 0.3822 & 0.8113 \\
\hline Blue Paint Locker & 0.1397 & 0.00 & 0.1377 & 0.1410 & 0.1091 & 0.1818 \\
\hline Blue $P$ aint $P$ allet & 0.1437 & 0.00 & 0.1429 & 0.1445 & 0.1081 & 0.1848 \\
\hline Tan $P$ aint $C$ ontainer & 0.4001 & 0.04 & 0.4797 & 0.5045 & 0.3834 & 0.5972 \\
\hline White $P$ aint Container & 0.4905 & 0.05 & 0.4742 & 0.5127 & 0.3999 & 0.5988 \\
\hline White $P$ aint Locker & 0.0972 & 0.01 & 0.0958 & 0.1000 & 0.07116127 & 0.1203 \\
\hline NUA Time & Aaerage & Half Wuidth & $\begin{array}{l}\text { Minimum } \\
\text { Aaserage }\end{array}$ & $\begin{array}{c}\text { Maximum } \\
\text { Aanerage }\end{array}$ & $\begin{array}{l}\text { Minimum } \\
\text { Value }\end{array}$ & $\begin{array}{l}\text { Meximum } \\
\text { Value }\end{array}$ \\
\hline Blue Paint Container & 0.5388 & 0.03 & 0.5272 & 0.5485 & 0.4255 & 0.6557 \\
\hline Blue $P$ aint Locker & 0.1846 & 0.00 & 0.1841 & 0.1849 & 0.1481 & 02280 \\
\hline Blue $P$ aint $P$ allet & 0.1884 & 0.00 & 0.1853 & 0.1875 & 0.1438 & 02369 \\
\hline Tan Paint $C$ ontainer & 0.5498 & 0.04 & 0.5349 & 0.5695 & 0.4232 & 08467 \\
\hline Wh hite $P$ aint Container & 0.5520 & 0.01 & 0.5498 & 0.5551 & 0.4557 & 0.6534 \\
\hline Wh hite Paint Lodker & 0.1372 & 0.01 & 0.1355 & 0.1398 & 0.1118 & 0.1839 \\
\hline W' ait Time & Awerage & Half Wuifdh & $\begin{array}{l}\text { Mulinimum } \\
\text { Aurerage }\end{array}$ & $\begin{array}{l}\text { Maximum } \\
\text { Amerage }\end{array}$ & $\begin{array}{c}\text { Minimum } \\
\text { Value }\end{array}$ & $\begin{array}{l}\text { Maximum } \\
\text { Value }\end{array}$ \\
\hline Blue Paint Container & 0.2486 & 0.18 & 0.1714 & 0.3142 & 0.00 & 1.5427 \\
\hline Blue Paint Locker & 0.6159 & 0.15 & 0.5634 & 0.6833 & 0.00 & 32557 \\
\hline Blue Paint Pallet & 0.5272 & 0.14 & 0.4634 & 0.5738 & 0.00 & 50953 \\
\hline Tan Paint C ontainer & 0.2878 & 0.08 & 0.2646 & 0.3260 & 0.00 & 1.4224 \\
\hline White $P$ aint Container & 0.2623 & 0.09 & 0.2295 & 0.3008 & 0.00 & 2.0673 \\
\hline Wuithite $P$ aint Lo dker & 0.3618 & 0.13 & 0.3108 & 0.4144 & 0.00 & 29264 \\
\hline Transfer Time & Anerage & Half Untondth & $\begin{array}{l}\text { Minirnum } \\
\text { Avrerage }\end{array}$ & $\begin{array}{l}\text { Maximum } \\
\text { Anerenge }\end{array}$ & $\begin{array}{l}\text { Minimum } \\
\text { Value }\end{array}$ & $\begin{array}{l}\text { Mrtaximum } \\
\text { Value }\end{array}$ \\
\hline Blue $P$ aint Container & 0.00 & 0.00 & 000 & 0.00 & 0.00 & 0.00 \\
\hline Blue Paint Locker & 0.00 & 0.00 & 000 & 0.00 & 0.00 & 0.00 \\
\hline Blue $P$ aint $P$ allet & 0.00 & 0.00 & 0.00 & 0.00 & 0.00 & 0.00 \\
\hline Tan $P$ aint $C$ ontainer & 0.00 & 0.00 & 0.00 & 0.00 & 0.00 & 0.00 \\
\hline Whithe Paint Container & 0.00 & 0.00 & 0.00 & 0.00 & 0.00 & 0.00 \\
\hline White Paint Lodker & 0.00 & 0.00 & 000 & 0.00 & 0.00 & 0.00 \\
\hline
\end{tabular}




\section{Denios Current $P$ ainting Process}

Replications: 3 Time Units: Days

\section{Entity}

\section{Time}

\begin{tabular}{|c|c|c|c|c|c|c|}
\hline Other Time & Anerage & Half voidth & $\begin{array}{l}\text { Minimum } \\
\text { Anerage }\end{array}$ & $\begin{array}{l}\text { Maximum } \\
\text { Auverage }\end{array}$ & $\begin{array}{l}\text { Minimum } \\
\text { Value }\end{array}$ & $\begin{array}{l}\text { Naximum } \\
\text { value }\end{array}$ \\
\hline Glue $P$ aint Container & 0.00 & 0.00 & 000 & 0.00 & 0.00 & 0.00 \\
\hline Elue $P$ a int Locker & 0.00 & 0.00 & 0.00 & 0.00 & 0.00 & $0 . \infty$ \\
\hline Blue $P$ aint $P$ allet & 0.00 & 0.00 & 0.00 & 0.00 & 0.00 & 0.00 \\
\hline Tan $P$ aint $C$ ontainer & 0.00 & 0.00 & 000 & 0.00 & 0.00 & 0.00 \\
\hline White Paint Container & 0.00 & 0.00 & 0.00 & 0.00 & 0.00 & $0 . \infty$ \\
\hline White Paint Locker & 0.00 & 0.00 & 000 & 0.00 & 0.00 & 0.00 \\
\hline Total Time & Awerage & Half Whith & $\begin{array}{l}\text { Minimum } \\
\text { Aarerage }\end{array}$ & $\begin{array}{c}\text { Mtaximum } \\
\text { Aunerage }\end{array}$ & $\begin{array}{l}\text { Minimum } \\
\text { Value }\end{array}$ & $\begin{array}{l}\text { Maximum } \\
\text { Value }\end{array}$ \\
\hline Elue Paint Container & 1.2882 & 0.17 & 1.2180 & 1.3560 & 0.8891 & $\overline{2.5328}$ \\
\hline Blue P aint Locker & 0.9401 & 0.15 & 0.8892 & 1.0051 & 0.2825 & 3.6042 \\
\hline Blue Paint Pallet & 0.8573 & 0.14 & 0.7924 & 0.9048 & 0.2708 & 5.4135 \\
\hline Tan Paint $C$ ontainer & 1.3337 & 0.03 & 1.3218 & 1.3411 & 0.9230 & 25995 \\
\hline White Paint Container & 1.3048 & 0.14 & 1.2650 & 1.3885 & 0.9845 & 3.1330 \\
\hline White Paint Locker & 0.5982 & 0.13 & 0.5419 & 0.8500 & 0.1994 & 3.1950 \\
\hline
\end{tabular}

Other 


\section{Denios Current $P$ ainting Process}

Replications: 3 Time Units: Days

\section{Entity}

\section{Other}

\begin{tabular}{lrrrr} 
N umber In & Awerage & Half Wufdth & $\begin{array}{r}\text { Minimum } \\
\text { Fuserage }\end{array}$ & $\begin{array}{r}\text { Maximum } \\
\text { Anserage }\end{array}$ \\
\hline Blue Paint Container & 51.0000 & 19.40 & 46.0000 & 60.0000 \\
Blue Paint Locker & 172.33 & 59.84 & 148.00 & 196.00 \\
Blue Paint Pallet & 1234.67 & 164.24 & 1164.00 & 1295.00 \\
Container & 83.6687 & 16.16 & 77.0000 & 90.0000 \\
Locker & 278.00 & 82.10 & 240.00 & 300.00 \\
Pallet & 926.00 & 116.50 & 876.00 & 969.00 \\
Tan Paint C ontainer & 17.0000 & 6.57 & 14.0000 & 19.0000 \\
White Paint Container & 15.6687 & 8.72 & 12.0000 & 19.0000 \\
White Paint Lacker & 84.0000 & 29.81 & 72.0000 & 96.0000
\end{tabular}

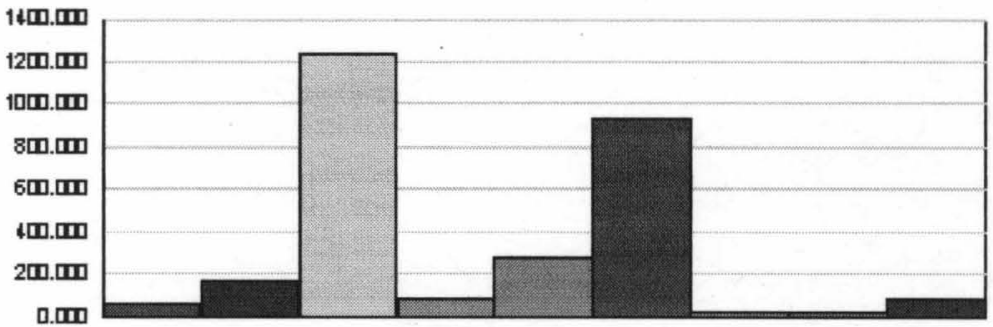

G Eumpralcantme

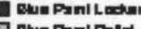
Q Eter Pant Pa Consan

Gim

10 ranPaniconian!

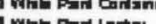

\begin{tabular}{lrrrr} 
Number Dut & Auerage & Half Midth & $\begin{array}{r}\text { Minimum } \\
\text { Aurerage }\end{array}$ & $\begin{array}{c}\text { Maximum } \\
\text { Auverage }\end{array}$ \\
\hline Blue Paint Container & 51.0000 & 19.40 & 46.0000 & 60.0000 \\
Blue Paint Locker & 172.33 & 59.64 & 148.00 & 196.00 \\
Blue Paint Pallet & 1234.33 & 164.05 & 1164.00 & 1295.00 \\
Container & 83.6667 & 16.16 & 77.0000 & 90.0000 \\
Locker & 278.00 & 82.10 & 240.00 & 300.00 \\
Pallet & 926.00 & 116.50 & 876.00 & 969.00 \\
Tan Paint C ontainer & 17.0000 & 6.57 & 14.0000 & 19.0000 \\
White Paint Container & 15.6667 & 8.72 & 12.0000 & 19.0000 \\
White Paint Locker & 84.0000 & 29.81 & 72.0000 & 96.0000
\end{tabular}




\section{Denios Current $P$ ainting Process}
Replications: 3
Time Units:
Days

\section{Entity}

\section{Other}

\begin{tabular}{|c|c|c|c|c|c|c|}
\hline WIIP & Awerage & Half width & $\begin{array}{l}\text { Minimum } \\
\text { Average }\end{array}$ & $\begin{array}{c}\text { Maximum } \\
\text { Aarerage }\end{array}$ & $\begin{array}{l}\text { Minimum } \\
\text { Value }\end{array}$ & $\begin{array}{l}\text { Maximum } \\
\text { Value }\end{array}$ \\
\hline Blue Paint Container & 0.2840 & 0.13 & 0.2290 & 0.3254 & 0.00 & $5 \overline{0000}$ \\
\hline Elue P aint Locker & 0.6185 & 0.31 & 0.4987 & 0.7468 & 0.00 & 110000 \\
\hline Elue $P$ aind $P$ allet & 3.9309 & 0.71 & 3.6438 & 4.2170 & 0.00 & 340000 \\
\hline Container & 0.00 & 0.00 & 0.00 & 0.00 & 0.00 & 10000 \\
\hline Locker & 0.00 & 0.00 & 000 & 0.00 & 0.00 & 30000 \\
\hline Pallet & 0.00 & 0.00 & 0.00 & 0.00 & 0.00 & 10000 \\
\hline Tan $P$ aint $C$ ontainer & 0.0907 & 0.03 & 0.07494300 & 0.1005 & 0.00 & 20000 \\
\hline White Paint Container & 0.08188084 & 0.05 & 0.06072073 & 0.0973 & 0.00 & 20000 \\
\hline White Paint Locker & 0.1905 & 0.06 & 0.1719 & 0.2184 & 0.00 & 60000 \\
\hline
\end{tabular}




\title{
Denios Current $P$ ainting Process
}

\author{
Replications: 3 Time Units: Days
}

\section{Queve}

\section{Time}

\begin{tabular}{|c|c|c|c|c|c|c|}
\hline Wrating Time & Average & Half Width & $\begin{array}{l}\text { Minimum } \\
\text { Average }\end{array}$ & $\begin{array}{c}\text { Maximum } \\
\text { Awerage }\end{array}$ & $\begin{array}{l}\text { Minimum } \\
\text { Value }\end{array}$ & $\begin{array}{l}\text { Maximum } \\
\text { Value }\end{array}$ \\
\hline $\begin{array}{l}\text { Batch Blue Pallets and } \\
\text { Lackers.Queue }\end{array}$ & 0.2359 & 0.00 & 0.2342 & 0.2377 & 0.00 & $\overline{39379}$ \\
\hline Batch Lodkers.Queue & 0.00 & 0.00 & 000 & 0.00 & 0.00 & 0.00 \\
\hline Batch White Lockers.Queve & 0.00 & 0.00 & 0.00 & 0.00 & 0.00 & 0.00 \\
\hline $\begin{array}{l}\text { Seize Painters for Container } \\
\text { Paint.Queue }\end{array}$ & 0.04688951 & 0.05 & 0.02157718 & 006274857 & 0.00 & 0.6598 \\
\hline $\begin{array}{l}\text { Seize Painters for } \\
\text { Containers.Queve }\end{array}$ & 0.2150 & 0.08 & 0.1937 & 0.2427 & 0.00 & 19971 \\
\hline $\begin{array}{l}\text { Seize } P \text { ainters for } P \text { all ets and } \\
\text { Locker Queve }\end{array}$ & 0.1505 & 0.05 & 0.1349 & 0.1768 & 0.00 & 1.1790 \\
\hline $\begin{array}{l}\text { Seize Painte is for White } \\
\text { Locker Queve }\end{array}$ & 0.1898 & 0.01 & 0.1876 & 0.1919 & 0.00 & 1.1946 \\
\hline $\begin{array}{l}\text { Seize Painters for Whithe } \\
\text { Lockers. Queve }\end{array}$ & 0.1721 & 0.13 & 0.1210 & 0.2268 & 0.00 & 2.4890 \\
\hline $\begin{array}{l}\text { Seize Prepaint for Pallets and } \\
\text { Lockers.Queve }\end{array}$ & 0.1432 & 0.10 & 0.1015 & 0.1792 & 0.00 & 2.5158 \\
\hline
\end{tabular}

\section{Other}

\begin{tabular}{|c|c|c|c|c|c|c|}
\hline Number W aiting & Aaerage & Half Width & $\begin{array}{l}\text { Minimum } \\
\text { Awerage }\end{array}$ & $\begin{array}{c}\text { Maximum } \\
\text { Awerage }\end{array}$ & $\begin{array}{l}\text { Minimum } \\
\text { Value }\end{array}$ & $\begin{array}{l}\text { Maximum } \\
\text { Value }\end{array}$ \\
\hline $\begin{array}{l}\text { Batch Blue Pallets and } \\
\text { Lockers.Queue }\end{array}$ & 0.9968 & 0.10 & 0.9564 & 1.00386 & 0.00 & 30000 \\
\hline Batch Lockers.Queue & 0.00 & 0.00 & 0.00 & 0.00 & 0.00 & 20000 \\
\hline Batch White Lockers.Queve & 0.00 & 0.00 & 000 & 0.00 & 0.00 & 20000 \\
\hline Pre Paint Prep Pallets.Queue & 0.00 & 0.00 & 000 & 0.00 & 0.00 & 0.00 \\
\hline $\begin{array}{l}\text { Seize } P \text { ainters for Container } \\
\text { Paint.Queue }\end{array}$ & 0.0151948 & 0.02 & 0.00664577 & 0.02258949 & 0.00 & 20000 \\
\hline $\begin{array}{l}\text { Seize Painters for } \\
\text { Containers.Queue }\end{array}$ & 0.07237732 & 0.03 & 0.05964916 & 0.08735589 & 0.00 & 40000 \\
\hline $\begin{array}{l}\text { Seize } P \text { ainters for } P \text { allets and } \\
\text { Locker.Queue }\end{array}$ & 0.2241 & 0.08 & 0.1878 & 0.2447 & 0.00 & 60000 \\
\hline $\begin{array}{l}\text { Seize } P \text { ainters for Withite } \\
\text { Looker Queve }\end{array}$ & 0.02124372 & 0.01 & 0.01842370 & 0.02429699 & 0.00 & 20000 \\
\hline $\begin{array}{l}\text { Secie } P \text { ainters for Wuhite } \\
\text { Lockers.Que ve }\end{array}$ & 0.01901951 & 0.01 & 0.01549007 & 0.02540149 & 0.00 & 20000 \\
\hline Seize Prepaint for Pallets and & 0.2012 & 0.13 & 0.1414 & 0.2437 & 0.00 & 60000 \\
\hline
\end{tabular}




\section{Denios Current $P$ ainting Process}

Vadues Across Ail kephogtions

Replications: 3 Time Units: Days

\section{Resource}

\section{Usage}

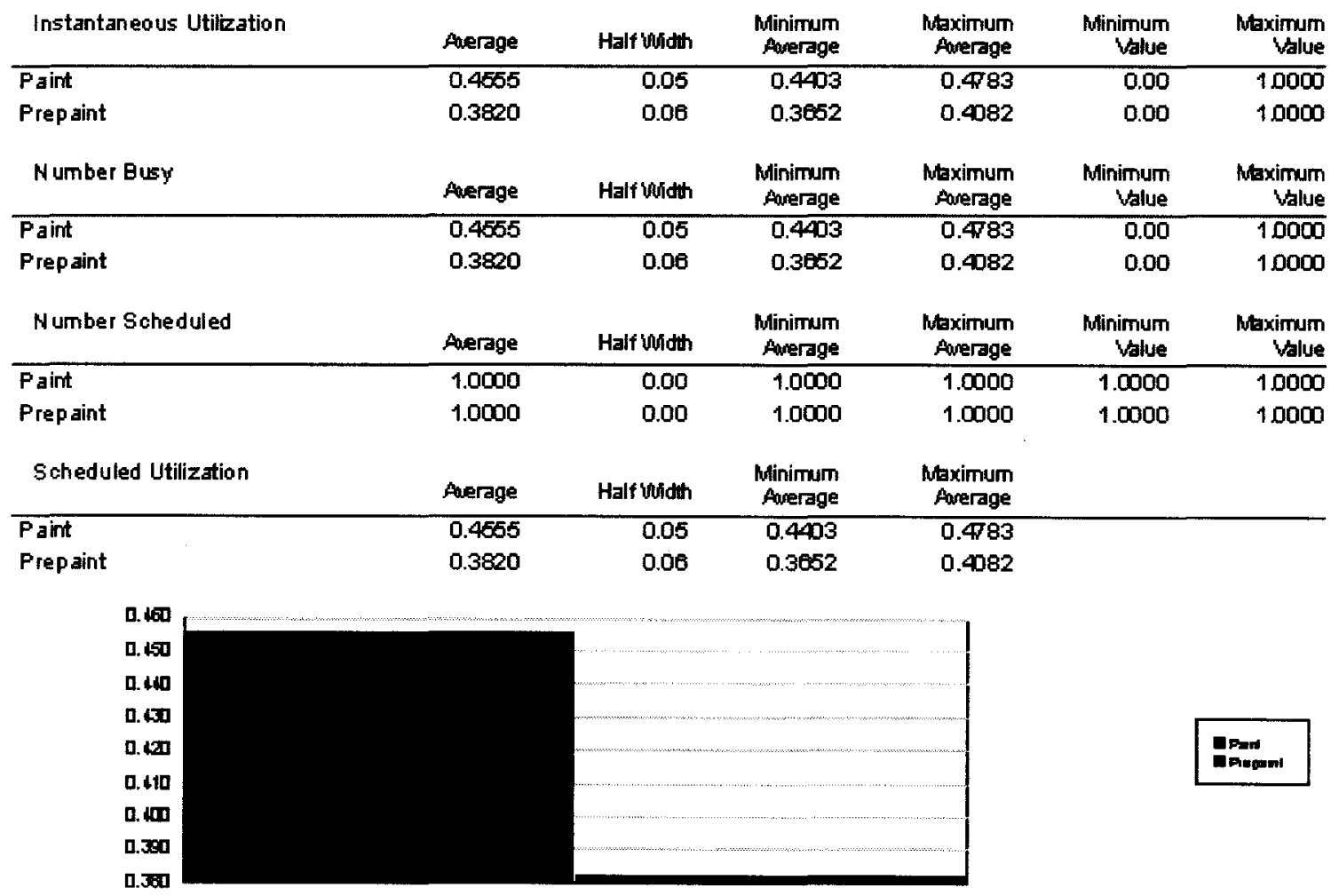

Model Filename : C:UUsersłPVD ocument W ofLWE600-ThesisłMo dified Mlode AP aint Modified Mc Page 


\section{Denios Current $P$ ainting Process}

Replications: 3 Time Units: Days

Resource

\section{Usage}

\begin{tabular}{lcccc} 
Total Number Seized & Anerage & Half Whidh & $\begin{array}{r}\text { Minimum } \\
\text { Average }\end{array}$ & $\begin{array}{r}\text { Maximum } \\
\text { Anerage }\end{array}$ \\
\hline Paint & 483.00 & 55.99 & 449.00 & 489.00 \\
Prepaint & 463.33 & 55.35 & 449.00 & 489.00
\end{tabular}

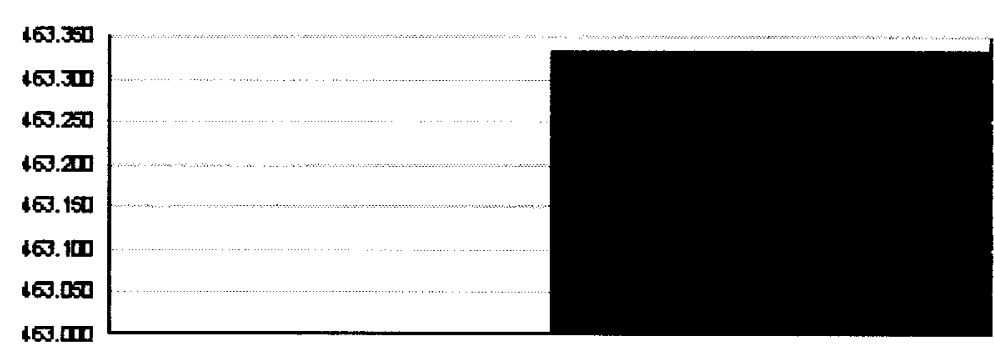

10.010 


\title{
CURRICULUM VITA
}

\author{
NAME: $\quad$ Paul-Victor Heitz \\ ADDRESS: 14 Gardiner $\mathrm{Ct}$. \\ Louisville, KY 40205 \\ DOB: $\quad$ Miami, FL - December 26, 1983 \\ EDUCATION \\ \& TRAINING: B.S., Mechanical Engineering \\ University of Dayton \\ 2002-2006
}

